\title{
Arsen i jego związki nieorganiczne Metoda oznaczania w powietrzu na stanowiskach pracy ${ }^{1}$
}

\author{
Arsen and its inorganic compounds \\ Determination in workplace air
}

mgr JOLANTA SURGIEWICZ

https://orcid.org/0000-0002-3936-5897

Centralny Instytut Ochrony Pracy - Państwowy Instytut Badawczy

Central Institute for Labour Protection - National Research Institute, Warsaw, Poland

Numer CAS 7440-38-2

\section{Streszczenie}

Arsen jest pierwiastkiem chemicznym zaliczanym do metaloidów (półmetali). Niektóre związki arsenu zostały sklasyfikowane (wg CLP) jako substancje rakotwórcze powodujące nowotwory skóry, układu oddechowego, wątroby i białaczkę. W przemyśle na arsen i jego związki narażeni są pracownicy zatrudnieni przy jego wydobyciu, w hutnictwie rud metali nieżelaznych, w procesach rafinacji metali, przy produkcji stopów, półprzewodników, pigmentów i insektycydów. Obowiązująca wartość normatywu higienicznego dla frakcji wdychalnej aerozolu arsenu i jego związków nieorganicznych w przeliczeniu na As w powietrzu na stanowiskach pracy wynosi $0,01 \mathrm{mg} / \mathrm{m}^{3}$. Opracowano metodę umożliwiającą oznaczanie tej substancji w powietrzu w zakresie $0,1 \div 2$ wartości normatywu higienicznego, zgodną z wymaganiami zawartymi w normie europejskiej PN-EN 482. Arsen oznacza się z wykorzystaniem absorpcyjnej spektrometrii atomowej z elektrotermiczną atomizacją (ET-AAS) w zakresie stężeń $5,00 \div 100,0 \mu \mathrm{g} / \mathrm{l}$, co pozwala na oznaczanie arsenu i jego nieorganicznych związków w powietrzu w zakresie: $0,0010 \div 0,021 \mathrm{mg} / \mathrm{m}^{3}$ (dla objętości próbki powietrza - $480 \mathrm{l}$ ). Przedstawiona procedura umożliwia oznaczanie tej substancji z zastosowaniem dozymetrii indywidualnej. Zakres tematyczny artykułu obejmuje zagadnienia zdrowia oraz bezpieczeństwa i higieny środowiska pracy będące przedmiotem badań z zakresu nauk o zdrowiu oraz inżynierii środowiska.

Słowa kluczowe: metale rakotwórcze, metoda analityczna, powietrze na stanowiskach pracy, narażenie zawodowe, nauki o zdrowiu, inżynieria środowiska.

\footnotetext{
Abstract

Arsenic is a chemical element classified as metalloids (semi-metals). Some arsenic compounds have been classified (according to CLP) as carcinogens, causing cancers of skin, respiratory system, liver and leukemia. In the industry, workers are exposed to arsenic and its compounds in its extraction, in metallurgy of non-ferrous metal ores, in metal

${ }^{1}$ Opracowano na podstawie wyników IV etapu programu wieloletniego „Poprawa bezpieczeństwa i warunków pracy”, finansowanego w latach 2017-2019 w zakresie zadań służb państwowych przez Ministerstwo Rodziny, Pracy i Polityki Społecznej (zadanie 1.G.02 pt.: Opracowanie znowelizowanych metod oznaczania 9 szkodliwych substancji chemicznych w powietrzu na stanowiskach pracy do oceny narażenia zawodowego). Koordynator programu: Centralny Instytut Ochrony Pracy - Państwowy Instytut Badawczy
} 
refining processes, in the production of alloys, semiconductors, pigments and insecticides. In Poland, binding value of the hygienic standard (NDS) at workplace air, for the inhalable fraction of arsenic aerosol and its inorganic compounds, converted into As is $0.01 \mathrm{mg} / \mathrm{m}^{3}$. A determination method has been developed that enables the determination of this substance in the air of $0.1-2$ values of the hygiene standard, in accordance with the requirements of Standard PN-EN 482. Arsenic is determined with the atomic absorption spectrometry with electrothermal atomization (ET-AAS), in the concentration range of $5.00-100.0 \mu \mathrm{g} / \mathrm{l}$ which allows the determination of arsenic and its compounds in workplace air in the range of $0.0010-0.021 \mathrm{mg} / \mathrm{m}^{3}$ (for $480-\mathrm{L}$ air sample). The presented procedure enables the determination of this substance with the use of individual dosimetry. This article discusses the problems of occupational safety and health, which are covered by health sciences and environmental engineering.

Keywords: carcinogenic metals, analytical method, workplace air, occupational exposure, health sciences, environmental engineering.

\section{WPROWADZENIE}

\section{Fizyczne i chemiczne właściwości arsenu i jego związków nieorganicznych}

Arsen (CAS: 7440-38-2) należy do 15. grupy (azotowce) i 4. okresu układu okresowego pierwiastków. Liczba atomowa arsenu wynosi 33, a masa atomowa 74,92 . W przyrodzie jest pierwiastkiem rzadkim $\left(5 \cdot 10^{-40} \%\right)$ i najczęściej występuje w postaci minerałów, np. arsenopirytu (FeAsS), aurypigmentu $\left(\mathrm{As}_{2} \mathrm{~S}_{3}\right)$ i realgaru (AsS), (Patnaik 2002; PubChem 2021a). Arsen otrzymuje się przez redukcję jego związków węglem lub przez ogrzewanie arsenopirytu. Tworzy dwie odmiany alotropowe. Odmianą trwałą jest arsen szary krystalizujący w układzie romboedrycznym i wykazujący słabe przewodnictwo elektryczne. Przez szybkie schłodzenie par arsenu tworzy się arsen żółty - odmiana nietrwała niemetaliczna, która podczas ogrzewania przechodzi $\mathrm{w}$ arsen szary. Temperatura topnienia arsenu wynosi $358^{\circ} \mathrm{C}$, a w temperaturze $613^{\circ} \mathrm{C}$ arsen sublimuje.

W związkach arsen występuje na stopniach utlenienia: V, III i -III. Najważniejszymi związkami są: arszenik - tritlenek arsenu, pentatlenek arsenu i kwas arsenowy (ATSDR 2016; PubChem 2021b).

Tritlenek arsenu (CAS: 1327-53-3, $\mathrm{As}_{2} \mathrm{O}_{3}$ ) jest białym, krystalicznym ciałem stałym. Występuje w dwóch odmianach alotropowych: oktaetrycznej lub sześciennej znanych $\mathrm{w}$ przyrodzie $\mathrm{w}$ postaci minerałów jako arsenolit oraz jednoskośnej jako klaudetyt. Arsenolit topi się w temperaturze $274^{\circ} \mathrm{C}$, a klaudetyt $\mathrm{w}$ temperaturze $313{ }^{\circ} \mathrm{C}$. Temperatura wrzenia tritlenku arsenu wynosi $460{ }^{\circ} \mathrm{C}$, sublimuje w temperaturze $100 \div 193{ }^{\circ} \mathrm{C}$ (wartość różna w zależności od źródeł: GESTIS 2021c; ILO 2008;
Patnaik 2002). Związek jest słabo rozpuszczalny w zimnej wodzie $\left(1,7 \% \mathrm{w} 25^{\circ} \mathrm{C}\right)$, ale jest rozpuszczalny w rozcieńczonych kwasach i zasadach; ma charakter amfoteryczny (Patnaik 2002; PubChem 2021b). Jest to bardzo silna trucizna; dawka $70 \div$ $180 \mathrm{mg}$ powoduje śmierć człowieka (Sitarek i in. 2003). Tritlenek arsenu stosuje się do wytwarzania metalicznego arsenu oraz szeregu związków arsenu. Jest stosowany $w$ pigmentach i emaliach ceramicznych i w wielu preparatach gryzoniobójczych. Tritlenek arsenu znajduje zastosowanie również $\mathrm{w}$ medycynie np. w terapii ostrej białaczki promielocytowej (Kulik-Kupka i in. 2016).

Pentatlenek arsenu (CAS: 1303-28-2, $\mathrm{As}_{2} \mathrm{O}_{5}$ ) to biała substancja amorficzna, bardzo dobrze rozpuszczalna w wodzie $\left(230 \mathrm{~g} / 100 \mathrm{~g} \mathrm{w} 20^{\circ} \mathrm{C}\right) \mathrm{i}$ alkoholu. Rozkłada się w temperaturze $315^{\circ} \mathrm{C}$. Pentatlenek arsenu jest używany do produkcji szkła kolorowego, fungicydów, kleju do metali oraz do produkcji arsenianów.

Kwas arsenowy(V) (CAS: 7778-39-4, $\mathrm{H}_{3} \mathrm{AsO}_{4}$. $\left.\cdot 0,5 \mathrm{H}_{2} \mathrm{O}\right)$ dostępny w handlu jest zwykle odpowiednikiem kwasu ortoarsenowego (CAS: 7774-41-6, $\mathrm{H}_{8} \mathrm{As}_{2} \mathrm{O}_{9}$ ), (jako półwodzian). Wodny roztwór tego kwasu zachowuje się jak kwas trójprotowy. Są również znane formy meta- i piro-: kwas metaarsenowy (CAS: 10102-53-1, $\mathrm{HAsO}_{3}$ lub $\mathrm{As}(\mathrm{OH}) \mathrm{O}_{2}$ ) i kwas piroarsenowy (CAS: 13453-15-1, $\mathrm{H}_{4} \mathrm{As}_{2} \mathrm{O}_{7}$ ). Wszystkie te formy podlegają konwersji. Kwas ortoarsenowy lub jego sól - ortoarsenian powstają, gdy formy meta- lub piro- są traktowane zimną wodą. Podobnie ogrzewanie w temperaturze $100^{\circ} \mathrm{C}$ przekształca kwas ortoarsenowy $\mathrm{w}$ kwas piroarsenowy. Dalsze ogrzewanie wytwarza kwas metaarsenowy. Kwas arsenowy(V) to higroskopijne półprze- 
zroczyste kryształy topiące się przy $35,5^{\circ} \mathrm{C}$, które tracą wodę po podgrzaniu do $160^{\circ} \mathrm{C}$. Jest dobrze rozpuszczalny $\mathrm{w}$ zimnej wodzie, rozpuszcza się w alkoholu, glicerolu i alkaliach. Reaguje z solami metali, tworząc ich ortoarseniany, np. $z$ azotanem srebra tworzy ortoarsenian srebra.

Kwas arsenowy(III) (CAS: 13464-58-9, $\mathrm{H}_{3} \mathrm{AsO}_{3}$ lub $\mathrm{As}(\mathrm{OH})_{3}$ ) to słaby kwas, który występuje tylko w roztworze. Powstaje w wyniku hydrolizy trójtlenku arsenu.

Inne związki arsenu: pentasiarczek arsenu (CAS: 1303-34-0, $\mathrm{As}_{2} \mathrm{~S}_{5}$ ) i trisiarczek arsenu (CAS: 1303-33-9, $\mathrm{As}_{2} \mathrm{~S}_{3}$ ) są ciałami stałymi (amorficznymi lub krystalicznymi) nierozpuszczalnymi w wodzie. Pentasiarczek arsenu stosuje się do barwienia szkła, produkcji fungicydów i konserwacji drewna.

Halogenki arsenu, np.: trichlorek arsenu (CAS: 7784-34-1, $\mathrm{AsCl}_{3}$ ) i trifluorek arsenu (CAS: 778435-2, $\mathrm{AsF}_{3}$ ), są oleistymi cieczami rozkładającymi się w wodzie. Stosuje się je w syntezie wielu związków arsenu o zastosowaniach medycznych i jako insektycydy. Trijodek arsenu (CAS: 7784-454, $\mathrm{AsJ}_{3}$ ) jest ciałem stałym słabo rozpuszczalnym w wodzie. Dawniej związek ten stosowano w zapaleniach skóry.

Arsenowodór (arsan), (CAS: 7784-42-1, $\mathrm{AsH}_{3}$ ) to gaz o nieprzyjemnym zapachu, słabo rozpuszczalny w wodzie. Jest związkiem redukującym stosowanym $\mathrm{w}$ syntezie wielu związków arsenowych oraz w elektronice. Arsenowodór to substancja silnie toksyczna i rakotwórcza. Narażenie na 250 ppm przez 30 min może być śmiertelne dla człowieka.

\section{Działanie toksyczne}

Arsen i jego związki działają toksycznie na ustrój człowieka. Są to substancje drażniące, toksyczne dla wątroby (hepatotoksyczne), układu krążenia i obwodowego układu nerwowego. Objawami zatrucia ostrego są kaszel i uczucie duszności. Skażenie oczu pyłem może wywołać ból i zaczerwienienie spojówek. Połknięcie może wywołać wymioty. Objawami zatrucia przewlekłego w przypadku długotrwałego narażenia na pył arsenu są: zanikowe zmiany w błonach śluzowych $\mathrm{z}$ perforacją przegrody nosowej, nadmierne rogowacenie, przebarwienia i kontaktowe zapalenie skóry, charakterystyczne białe poprzeczne linie (linie Meesa) w paznokciach oraz cechy uszkodzenia wątroby, zmiany w naczyniach obwodowych (włosowatych) z zasinieniem palców rąk i stóp, zmiany w mięśniu sercowym oraz zmiany we krwi. Odległym następstwem długotrwałego narażenia są nowotwory: skóry, układu oddechowego i wątroby oraz białaczka (HSDB 2018; Sitarek i in. 2003), a także uszkodzenie układu nerwowego, zaburzenia sfery psychicznej i polineuropatie czuciowo-ruchowe mogące prowadzić do porażenia kończyn (Sińczuk-Walczak 2009).

Według Rozporządzenia Parlamentu Europejskiego i Rady (WE) nr 1272/2008 (CLP) ze względu na zagrożenie dla zdrowia ludzi arsen został sklasyfikowany jako substancja: wykazująca toksyczność ostrą przez drogi oddechowe - kategoria zagrożenia 3., wykazująca toksyczność ostrą drogą pokarmową - kategoria zagrożenia 3., stwarzająca zagrożenie dla środowiska wodnego - zagrożenie ostre - kategoria zagrożenia 1. oraz stwarzająca zagrożenie dla środowiska wodnego - zagrożenie przewlekłe - kategoria zagrożenia 1.

Oznakowanie CLP dla arsenu zawiera znaki piktogramy GHS:

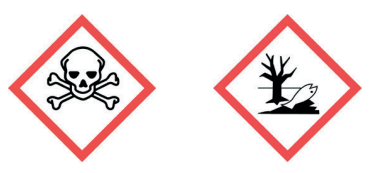

Arsenowi przypisano zwroty wskazujące rodzaj zagrożenia $(\mathrm{H})$ :

H301: Działa toksycznie po połknięciu.

H331: Działa toksycznie w następstwie wdychania. H410: Działa bardzo toksycznie na organizmy wodne, powodując długotrwałe skutki (ECHA 2021a).

Związki arsenu, takie jak tritlenek diarsenu, pentatlenek diarsenu czy kwas arsenowy i jego sole, sklasyfikowano ponadto jako kancerogenne kategoria zagrożenia 1A, z przypisanym zwrotem zagrożenia dla substancji rakotwórczych: H350: może powodować raka.

Oznakowanie CLP dla tritlenku arsenu zawiera znaki - piktogramy GHS:
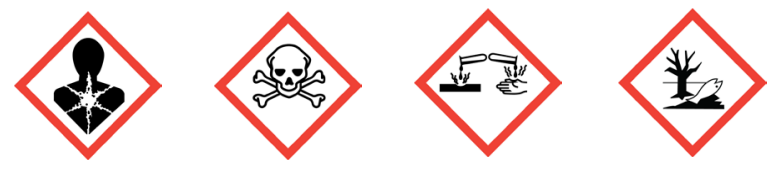

oraz następujące zwroty wskazujące rodzaj zagrożenia $(\mathrm{H})$ :

H300: Połknięcie grozi śmiercią.

H301: Działa toksycznie po połknięciu. 
H314: Powoduje poważne oparzenia oraz uszkodzenie oczu.

H331: Działa toksycznie w następstwie wdychania. H350: Może powodować raka.

H400: Działa bardzo toksycznie na organizmy wodne.

H410: Działa bardzo toksycznie na organizmy wodne, powodując długotrwałe skutki (ECHA 2021b; Rozporządzenie WE... 2008).

Wartość normatywu higienicznego (NDS) podana w obowiązującym rozporządzeniu Ministra Rodziny, Pracy i Polityki Społecznej w sprawie najwyższych dopuszczalnych stężeń i natężeń czynników szkodliwych dla zdrowia w środowisku pracy dla arsenu i jego związków nieorganicznych w przeliczeniu na As - frakcja wdychalna wynosi $0,01 \mathrm{mg} / \mathrm{m}^{3}$ (Rozporządzenie... 2018).

Narażenie zawodowe na arsen i jego związki nieorganiczne występuje głównie w czasie wydobywania i przetwarzania rud arsenowych, w hutnictwie, szczególnie w czasie rafinacji ołowiu i miedzi, przy produkcji stopów, przy wytwarzaniu półprzewodników, pigmentów i emalii ceramicznych, przy produkcji preparatów gryzoniobójczych, przy produkcji chemioterapeutyków, a także przy impregnacji drewna i skóry do celów muzealnych (GESTIS 2021a; 2021b; 2021c; Patnaik 2002). Najbardziej narażone są osoby zatrudnione w hutnictwie miedzi. Stwierdzono, że na niektórych stanowiskach, np. pracowników pieców anodowych, przygotowania wsadów czy rafiniarzy, stężenia arsenu znacznie przekraczały (niekiedy dwukrotnie, a nawet trzykrotnie) wartość $0,05 \mathrm{mg} / \mathrm{m}^{3}$ (Jakubowski 2000).

\section{Metody analityczne stosowane do oceny środowiska pracy}

Sposób oznaczania arsenu i jego związków na stanowiskach pracy do celów oceny narażenia zawodowego zawarty jest w znormalizowanej metodzie: PN-Z-04011-8:2004 - Ochrona czystości powietrza - Badania zawartości arsenu i jego związków - Oznaczanie na stanowiskach pracy metodą wodorkową absorpcyjnej spektrometrii atomowej. $\mathrm{W}$ normie podano metodę polegającą na osadzeniu arsenu i jego związków, w tym tritlenku arsenu, na filtrze membranowym i impregnowanym filtrze membranowym, mineralizacji filtrów przy użyciu stężonego kwasu azotowego(V) i siarkowego(VI) $\mathrm{z}$ dodatkiem nadtlenku wodoru oraz analizie otrzymanego roztworu metodą absorpcyjnej spektrometrii atomowej po generacji wodorku arsenu (HG-AAS), przy długości fali 193,7 nm. Metoda opisana w normie umożliwia oznaczenie najmniejszej ilości arsenu i jego związków w powietrzu na stanowiskach pracy na poziomie $0,0023 \mathrm{mg} / \mathrm{m}^{3}$, co stanowi około $1 / 5$ wartości NDS, i została przeznaczona do nowelizacji.

Opisane $\mathrm{w}$ dostępnej literaturze procedury oznaczania arsenu i jego związków stosowane do analizy powietrza na stanowiskach pracy często wykorzystują technikę analityczną generacji wodorków absorpcyjnej spektrometrii atomowej (HG-AAS), gdyż jest to metoda czuła i umożliwiająca oznaczanie niskich stężeń arsenu. Technikę tę zastosowano w metodzie ISO 11041 i uzyskano granicę oznaczania ilościowego wynoszącą $0,00005 \mathrm{mg} / \mathrm{m}^{3}$ (dla 9601 powietrza). Do pobierania frakcji wdychalnej arsenu i jego związków zastosowano filtr MCE (Mixed Cellulose Ester), a dodatkowo do pobierania powietrza zawierającego lotny $\mathrm{As}_{2} \mathrm{O}_{3}$ zastosowano umieszczoną za filtrem impregnowaną przy użyciu $\mathrm{Na}_{2} \mathrm{CO}_{3}$ podkładkę celulozową (back-up paper pad), (ISO 11041:1996). Próbkę mineralizowano z użyciem kwasów azotowego i siarkowego oraz diltenku diwodoru. Metoda ta jest podobna do metody MDHS 41/2, w której uzyskano identyczną granicę oznaczalności. Do oznaczania frakcji wdychalnej próbkę powietrza pobierano z przepływem 2 l/min (MDHS 1995). Opublikowana w 1990 r. metoda BIA 6195-2 z zastosowaniem generacji wodorków do oznaczania arsenu umożliwiała uzyskanie granicy oznaczania ilościowego na poziomie $0,002 \mathrm{mg} / \mathrm{m}^{3}$ dla objętości powietrza $420 \mathrm{l}$ i przy przepływie $3,5 \mathrm{l} / \mathrm{min}$. Do pobierania próbek powietrza zastosowano filtry z włókna szklanego, jednak stosując tę metodę, nie można było oznaczyć tritlenku arsenu $\left(\mathrm{As}_{2} \mathrm{O}_{3}\right)$ występującego w postaci par (BIA 1990). Podobnie metoda NIOSH 7900, również wykorzystująca technikę generacji wodorków AAS, stosowana do oznaczania arsenu i jego związków we frakcji wdychalnej, uniemożliwia ilościowe oznaczanie tritlen$\mathrm{ku}$ arsenu, chociaż zastosowanie metody pozwala na oznaczanie arsenu $\mathrm{w}$ powietrzu na poziomie $0,0002 \mathrm{mg} / \mathrm{m}^{3}$ (dla objętości próbki powietrza $480 \mathrm{l}$ ), (NIOSH 1994a). 
Do oceny warunków pracy i oznaczania stężeń arsenu i jego nieorganicznych związków równie często jak metoda HG-AAS jest stosowana absorpcyjna spektrometria atomowa $\mathrm{z}$ elektrotermiczną atomizacją w kuwecie grafitowej (ET-AAS). Zastosowanie tego typu atomizacji do oznaczania arsenu nie zapewnia uzyskania niższej granicy oznaczania ilościowego, jednak ze względu na lepszą odtwarzalność jest to metoda godna polecenia. Z zastosowaniem tej techniki możliwe było oznaczanie ilościowe arsenu na poziomie $0,002 \mathrm{mg} / \mathrm{m}^{3}$ (dla 4201 pobranego powietrza), (BIA 1989). Z wykorzystaniem elektrotermicznej atomizacji oznaczano również tritlenek arsenu na poziomie $0,001 \mathrm{mg} / \mathrm{m}^{3}$ (dla próbki powietrza 200 l) metodą opisaną w NIOSH 7901. Ze względu na własności tego związku próbkę powietrza pobierano na filtr MCE impregnowany węglanem sodu z podkładka celulozową (NIOSH 1994b). Opisana w 1991 r. metoda OSHA ID-105 umożliwiała oznaczanie nieorganicznego arsenu w powietrzu na stanowiskach pracy $\mathrm{z}$ wykorzystaniem elektrotermicznej atomizacji i uzyskanie granicy oznaczalności na poziomie $0,0005 \mathrm{mg} / \mathrm{m}^{3}$ dla próbki powietrza $480 \mathrm{l}$, którą pobierano z przepływem $21 /$ min na filtr $z$ estrów celulozy $z$ celulozową podkładką impregnowaną roztworem węglanu sodu. W przypadku występowania w powietrzu gazu $\mathrm{AsH}_{3}$ próbkę zalecano pobierać $\mathrm{z}$ niższym strumieniem objętości - 0,5 1/min, a za filtrem stosować rurkę szklaną wypełnioną dwoma warstwami węgla aktywnego - 400 i $200 \mathrm{mg}$ (OSHA 1991). Metoda ta nie jest obecnie rekomendowana przez OSHA.

Do oznaczania arsenu i jego związków w powietrzu na stanowiskach pracy wykorzystuje się również metodę spektrometrii emisyjnej ze wzbudzeniem w plazmie sprzężonej indukcyjnie (ICP-AES), która umożliwia uzyskanie oznaczalności arsenu na poziomie: $0,0005 \mathrm{mg} / \mathrm{m}^{3}$ (dla objętości pobranego powietrza $500 \mathrm{l}$ ). W metodach NIOSH 7300 i NIOSH 7301 deklarowany zakres oznaczania wszystkich $\mathrm{z}$ ponad 30 pierwiastków jest bardzo szeroki i zawiera się $\mathrm{w}$ granicach $0,005 \div$ $2,0 \mathrm{mg} / \mathrm{m}^{3}$. W metodzie NIOSH 7303 oznaczalność wybranego pierwiastka zależna jest od oznaczalności tego pierwiastka $\mathrm{w}$ roztworze. Dla arsenu oznaczalność wynosi $0,0005 \mathrm{mg} / \mathrm{m}^{3}$ (dla próbki powietrza 480 l), deklarowany górny zakres oznaczania wszystkich pierwiastków wynosi ponad $100 \mathrm{mg} / \mathrm{m}^{3}$ (NIOSH 2003a; 2003b; 2003c). Metody
NIOSH zalecają pobieranie próbek powietrza na filtry nitrocelulozowe lub z PVC, lecz nie zalecano próbników do pobierania frakcji wdychalnej. Do mineralizacji próbek w metodzie NIOSH 7300 stosowano kwas azotowy oraz ditlenek diwodoru, w metodzie NIOSH 7301 stosowano kwas azotowy i nadchlorowy, a w metodzie NIOSH 7303 kwas solny i azotowy. Ze względu na sposób pobierania próbki powietrza metody te są klasyfikowane jako nieilościowe w stosunku do tritlenku diarsenu.

Obecnie w piątym wydaniu zbioru metod NIOSH do oznaczania arsenu preferowane są metody: NIOSH 7302, NIOSH 7304 (z mikrofalową atomizacją próbki) i NIOSH 7306, w których z wykorzystaniem ICP-AES oprócz arsenu można jednocześnie oznaczać również ponad 30 innych pierwiastków i ich związków zawartych w powietrzu w postaci aerozolu (NIOSH 2014a; 2014b). W metodzie NIOSH 7306 do pobierania próbek powietrza zastosowano ponadto próbnik zawierający wewnętrzną kapsułę z octanu celulozy przymocowaną do filtra membranowego MCE, która zapobiega stratom próbki na ściankach próbnika. Nie stosowano tu specjalnego pobierania próbki w celu pochłonięcia również lotnych związków arsenu (NIOSH 2015a). W zbiorze metod rekomendowanych przez NIOSH znajduje się także metoda NIOSH 6001 stosowana do oznaczania arsanu (arsenowodoru) - gazu, do którego pochłaniania zastosowano próbnik $\mathrm{z}$ węgla aktywnego $(100 \mathrm{mg} /$ $50 \mathrm{mg}$ ), (NIOSH 2015b).

W zbiorach metod OSHA do oznaczania arsenu zalecana jest obecnie metoda OSHA 1006 służąca również do oznaczania kadmu, kobaltu, miedzi, ołowiu i niklu. Do pobierania próbek powietrza zaleca się użycie gotowego próbnika, który umożliwia pochłanianie również par $\mathrm{As}_{2} \mathrm{O}_{3}$ (OSHA 2005). Próbnik zbudowany jest $\mathrm{z}$ filtra MCE i impregnowanej węglanem sodu podkładki celulozowej umieszczonej w komorze próbnika. Oznaczanie metali wykonuje się metodą spektrometrii mas z jonizacją w plazmie sprzężonej indukcyjnie (ICP-MS). Próbnika tego nie można jednak zastosować do pobierania frakcji wdychalnej (SKC 1992). W zbiorze metod zalecanych przez OSHA znajduje się jeszcze jedna metoda (OSHA 5003) umożliwiająca oznaczanie As, Cd i $\mathrm{Pb}$ techniką ICP-MS po pobraniu próbki powietrza przy użyciu filtra MCE. W metodzie zastosowano mikrofalowy rozkład próbki w połączeniu 
z aparaturą spektrometrii mas z plazmą sprzężoną indukcyjnie (ICP-MS). Metoda dotyczy tylko aerozolu stałego zawartego w powietrzu, a próbkę pobiera się wyłącznie na filtr MCE. W przypadku obecności lotnych związków arsenu np. gazów $\mathrm{AsH}_{3}$ pobieranie próbek i analizę procedura OSHA zaleca wykonać zgodnie z metodą NIOSH 6001 (NIOSH 1994c). Gdy temperatura procesu technologicznego przekracza $800{ }^{\circ} \mathrm{C}$, arsen może przekształcić się $\mathrm{w}$ tritlenek arsenu $\left(\mathrm{As}_{2} \mathrm{O}_{3}\right) \mathrm{w}$ postaci par - w takim przypadku OSHA zaleca, aby zapoznać się z instrukcjami zawartymi w metodzie NIOSH 7901 (OSHA 2019).

Opracowano i opisano poniżej dwie wersje metody oznaczania arsenu i jego związków nieorganicznych z wykorzystaniem absorpcyjnej spektrometrii atomowej z elektrotermiczną atomizacją (ET-AAS). Zastosowanie tej techniki analitycznej pozwala na uzyskanie oznaczalności metody na poziomie $0,001 \mathrm{mg} / \mathrm{m}^{3}$. Zgodnie $\mathrm{z}$ opracowaną metodą powietrze stanowisk pracy zawierające aerozol arsenu i jego związków nieorganicznych przepuszcza się przez filtr membranowy z estrów celulozy MCE. Pobraną na filtr próbkę powietrza mineralizuje się z użyciem stężonego kwasu azotowego $(\mathrm{V}) \mathrm{z}$ dodatkiem ditlenku diwodoru i sporządza roztwór do analizy $\mathrm{w}$ rozcieńczonym kwasie azotowym. Arsen w otrzymanym roztworze oznacza się z zastosowaniem modyfikacji matrycy, przy długości fali 193,7 nm. W przypadku niektórych wysokotemperaturowych procesów przemysłowych, w których istnieje możliwość wystąpienia związków arsenu (np. tritlenku arsenu) w postaci par (w warunkach normalnych jest on ciałem stałym), zastosowano metodę zmodyfikowaną, w której próbkę zaleca się pobierać na filtr MCE z podkładką celulozową impregnowaną roztworem węglanu sodowego w glicerynie. Podkładka celulozowa (tzw. back-up pad) jest bardzo dobrze zwilżalna tym roztworem i pary tritlenku arsenu wchodzą w reakcję z osadzonym na niej węglanem sodu zgodnie $\mathrm{z}$ zapisem:

$$
\mathrm{As}_{2} \mathrm{O}_{3}+\mathrm{Na}_{2} \mathrm{CO}_{3} \rightarrow 2 \mathrm{NaAsO}_{2}+\mathrm{CO}_{2},
$$

co zastosowano w metodach: ISO 11041, MDHS 41/2, OSHA 1006 (ISO 1996; MDHS 1995; OSHA 2005).

W przypadku użycia do pobierania próbek powietrza filtra i impregnowanej podkładki celulozowej należy zastosować inny sposób mineralizacji próbki - przy użyciu stężonego kwasu azotowego(V), kwasu siarkowego(VI) oraz ditlenku diwodoru. Po sporządzeniu roztworu do analizy ilościowej arsen oznacza się również metodą absorpcyjnej spektrometrii atomowej $\mathrm{z}$ elektrotermiczną atomizacją $\mathrm{w}$ kuwecie grafitowej, lecz w innych warunkach temperaturowych.

\section{CZĘŚĆ DOŚWIADCZALNA}

\section{Aparatura i stosowany sprzęt}

W badaniach stosowano spektrofotometr absorpcji atomowej AAnalyst 600 firmy Perkin Elmer Corporation umożliwiający oznaczanie arsenu przy użyciu elektrotermicznej atomizacji w kuwecie grafitowej, z korekcją tła metodą Zeemana, wyposażony $\mathrm{w}$ lampę $\mathrm{z}$ wyładowaniem bezelektrodowym (EDL) do oznaczania arsenu, automatyczny podajnik próbek oraz pokrywane pirolitycznie kuwety z platformą do oznaczania pierwiastków lotnych. W badaniach stosowano wodę demineralizowaną o oporności 18,2 $\mathrm{M} \Omega$ (w temp. $25^{\circ} \mathrm{C}$ ) z systemu Milli-Q (Millipore, USA). Badania sprawdzające przyjęty sposób przygotowania próbki do oznaczania przeprowadzono $\mathrm{z}$ użyciem filtrów membranowych z estrów celulozy (MCE) o średnicy porów 0,8 mm i podkładek celulozowych (SKC, USA). Do sporządzania roztworów używano pipet automatycznych (Brand, Niemcy) oraz jednomiarowych pipet ze szkła borowo-krzemowego klasy A (PZ HTL SA, Polska). W badaniach używano wyłącznie naczyń ze szkła borowo-krzemowego klasy A (lub polietylenu). Do przechowywania roztworów używano naczyń $\mathrm{z}$ polietylenu. Badane próbki mineralizowano w zlewkach o pojemności $25 \mathrm{ml}$ na płycie grzejnej (temp. ok. $140^{\circ} \mathrm{C}$ ).

\section{Odczynniki i roztwory}

Podczas badań stosowano następujące odczynniki: kwas azotowy(V), o stężeniu $65 \%, d=1,42 \mathrm{~g} / \mathrm{ml}$, Suprapure, (Merck, Niemcy), kwas azotowy(V), 
roztwór o stężeniach 1 i $0,1 \mathrm{~mol} / \mathrm{l}$, kwas siarkowy(VI), o stężeniu 96\%, $d=1,84 \mathrm{~g} / \mathrm{ml}$ (Carl Roth, Niemcy), arsen, roztwór wzorcowy do absorpcji atomowej o stężeniu $1 \mathrm{mg} / \mathrm{ml}$ (GUM, Polska), arsen, roztwór wzorcowy pośredni o stężeniu $10,0 \mu \mathrm{g} / \mathrm{l}$, roztwór roboczy arsenu o stężeniach $1,00 \mu \mathrm{g} / \mathrm{ml}$ oraz $100,0 \mu \mathrm{g} / \mathrm{l}$, a ponadto palladowy modyfikator matrycy, roztwór o $c(\mathrm{Pd})=10 \mathrm{~g} / \mathrm{l}$, azotan palladu $\mathrm{Pd}\left(\mathrm{NO}_{3}\right)_{2}$ (Merck, Niemcy) i magnezowy modyfikator matrycy, roztwór o $c(\mathrm{Mg})=$ $10 \mathrm{~g} / \mathrm{l}$, azotan magnezu $\mathrm{Mg}\left(\mathrm{NO}_{3}\right)_{2}$, (Merck, Niemcy), roztwór azotanu palladu i azotanu magnezu o stężeniach 0,005 i 0,003 mg w analizowanej próbce oraz węglan sodu (POCh, Polska), roztwór o stężeniu $1 \mathrm{~mol} / \mathrm{l}$ w roztworze gliceryny o ułamku objętościowym 5\% (POCh, Polska). Ponadto stosowano argon sprężony N 5.0 o stopniu czystości analizowany czysty lub wg instrukcji do aparatu.

\section{Parametry oznaczania}

Oznaczanie arsenu metodą absorpcyjnej spektrometrii atomowej (ET-AAS) $\mathrm{z}$ atomizacją $\mathrm{w}$ kuwecie grafitowej, z korekcją tła metodą Zeemana, prowadzono przy długości fali 193,7 nm. W badaniach przyjęto parametry oznaczania wyznaczone eksperymentalnie przez ich optymalizację dla próbki przygotowanej analizy po mineralizacji czystego filtra MCE lub czystego filtra MCE i impregnowanej podkładki celulozowej (w zależności od opracowywanej metody). Optymalizacja dotyczyła parametrów takich jak: dobór modyfikatorów matrycy oraz parametrów programu atomizacji, w tym: temperatury i czasu etapu suszenia, spopielania i atomizacji próbki dla zastosowanych do mineralizacji różnych kwasów.

Najlepszą czułość i precyzję oznaczania arsenu dla kuwety grafitowej pokrywanej pirolitycznie, z platformą i przeznaczonej do oznaczania pierwiastków lotnych, uzyskano dla roztworów arsenu sporządzonych w roztworze rozcieńczonego kwasu azotowego i dla roztworów z matrycą kwasu siarkowego przy zastosowaniu następujących warunków pracy spektrofotometru:

- długość fali - 193,7 nm

- lampa z wyładowaniem bezelektrodowym (EDL) do oznaczania arsenu

- szczelina - 0,7 nm

- całkowita objętość dozowanej próbki - 20 lub $25 \mu \mathrm{l}$

- objętość dozowanego modyfikatora matrycy $-5 \mu \mathrm{l}$
- temperatura suszenia próbki -110 i $130{ }^{\circ} \mathrm{C}$, czas $-75 \mathrm{~s}$

- temperatura spopielania roztworu zawierającego kwas azotowy: $1100{ }^{\circ} \mathrm{C}$, czas $-30 \mathrm{~s}$

- temperatura spopielania roztworu zawierającego kwas azotowy i siarkowy: $700{ }^{\circ} \mathrm{C}$, czas - $40 \mathrm{~s}$

- temperatura atomizacji $-2300{ }^{\circ} \mathrm{C}$, czas 3 lub $5 \mathrm{~s}$.

\section{Krzywa wzorcowa oraz precyzja oznaczania arsenu metodą ET-AAS}

Krzywa wzorcowa dla próbek sporządzonych w kwasie azotowym o stężeniu $0,1 \mathrm{~mol} / \mathrm{l}$ była wykonywana $\mathrm{z}$ jednego roztworu wzorcowego roboczego arsenu o stężeniu $100 \mu \mathrm{g} / \mathrm{l}$ przy użyciu automatycznego podajnika próbek do sporządzenia roztworów wzorcowych o stężeniach: 10, 25, 50 i $100 \mu \mathrm{g} / \mathrm{l}$. Skład roztworu stosowanego do rozcieńczania był identyczny jak matrycy (roztwór kwasu azotowego o stężeniu $0,1 \mathrm{~mol} / \mathrm{l}$ ), dodatkowo do kuwety dozowano modyfikator matrycy Pd i Mg o stężeniach 0,005 i 0,003 mg w analizowanej próbce. Oznaczanie arsenu wykonywano w podanych wyżej warunkach instrumentalnych. Dla każdego roztworu dozowanego dwukrotnie do kuwety wykonywano dwa odczyty absorbancji. Do pomiaru próbki zerowej używano roztworu kwasu azotowego o stężeniu $0,1 \mathrm{~mol} / \mathrm{l} \mathrm{z}$ dozowanym do atomizacji modyfikatorem matrycy. Kalibrację powtarzano co dziesięć analizowanych próbek. Średnia wartość absorbancji skorygowanej o wartość absorbancji dla próbki zerowej, obliczana przez oprogramowanie aparatu, umożliwia podanie stężenia arsenu $\mathrm{w}$ analizowanej próbce $\mathrm{w}$ mikrogramach w litrze roztworu.

Do oceny precyzji wyników oznaczeń kalibracyjnych wykonano trzy serie krzywych kalibracji $\mathrm{z}$ trzech niezależnych serii roztworów wzorcowych. Uzyskana krzywa kalibracji w wybranym zakresie stężeń $10 \div 100 \mu \mathrm{g} / \mathrm{l}$ ma charakter liniowy, przypisano jej funkcję: $y=0,0041 x-0,0027$. Masa charakterystyczna oznaczania arsenu wyniosła 20,1 pg. Krzywą kalibracji przedstawiono na rycinie 1.

Do oceny powtarzalności i dokładności wyników pomiarów wykonano serie oznaczeń arsenu w roztworach modelowych. Przygotowano po siedem próbek o tym samym stężeniu arsenu dla trzech poziomów stężeń arsenu z zakresu krzywej 
wzorcowej: 20, 40 i $80 \mu \mathrm{g} / \mathrm{l}$ i wykonano oznaczenia arsenu w roztworach modelowych. Uzyskane wartości stężeń wykazują dobrą powtarzalność. Współczynnik zmienności CV wynosił odpowiednio: 0,$94 ; 1,02$ i $0,81 \%$. Średni błąd względny wynosił odpowiednio: 1,$01 ; 0,81$ i $0,53 \%$.

Zakres pomiarowy: $10 \div 100,0 \mu \mathrm{g} / \mathrm{l}$ oznaczania arsenu w roztworze kwasu azotowego o stężeniu $0,1 \mathrm{~mol} / 1$ odpowiada zakresowi stężeń arsenu i jego związków nieorganicznych (w przeliczeniu na arsen) w powietrzu: $0,0010 \div 0,010 \mathrm{mg} / \mathrm{m}^{3}$ (dla objętości analizowanego roztworu po mineralizacji - $25 \mathrm{ml}$ i objętości próbki powietrza - $240 \mathrm{l}$ oraz objętości roztworu po mineralizacji - $50 \mathrm{ml}$ i objętości próbki powietrza - $480 \mathrm{l}$ ) i stanowi $0,1 \div 1$ wartości NDS.

Dla próbek zawierających matrycę kwasu siarkowego po mineralizacji filtrów $\mathrm{z}$ estrów celulozy i impregnowanych węglanem sodu celulozowych podkładek wykonano drugą krzywa wzorcową $\mathrm{z}$ jednego roztworu wzorcowego roboczego o stężeniu $100 \mu \mathrm{g} / \mathrm{l}$ przy użyciu automatycznego podajnika próbek. Każdy z roboczych roztworów wzorcowych o stężeniach: 5, 25, 50, 75 i $100 \mu \mathrm{g} / \mathrm{l}$ dozowano do kuwety grafitowej dwukrotnie. Roztwór stosowany do rozcieńczania roztworów wzorcowych stanowił roztwór próbki zerowej po mineralizacji, ponadto do kuwety dozowano modyfikator matrycy Pd i Mg o stężeniach 0,005 i 0,003 $\mathrm{mg} \mathrm{w}$ analizowanej próbce.
Analizy wykonywano w warunkach zoptymalizowanych dla roztworu arsenu zawierającego matrycę kwasu siarkowego. Dla każdego podawanego do kuwety spektrofotometru roztworu wykonywano dwa odczyty absorbancji. Do pomiaru próbki zerowej używano rozcieńczonego roztworu próbki zerowej - po mineralizacji z dozowanym do atomizacji roztworem modyfikatora matrycy. Kalibrację powtarzano co sześć analizowanych próbek. Mierzona absorbancja, skorygowana o wartość absorbancji dla próbki zerowej, umożliwia obliczenie przez oprogramowanie aparatu stężenia arsenu $\mathrm{w}$ analizowanej próbce.

Do oceny powtarzalności wykonano trzy serie krzywych kalibracji z trzech niezależnych serii roztworów wzorcowych. Uzyskana krzywa jest liniowa w badanym zakresie stężeń $5,00 \div 100,0 \mu \mathrm{g} / \mathrm{l}$, przypisano jej funkcję: $y=0,0044 x+0,002$. Masa charakterystyczna arsenu wyniosła 22 pg. Krzywą kalibracji przedstawiono na rycinie 2 .

W celu oceny powtarzalności i dokładności wyników pomiarów wykonanych na podstawie tej krzywej wzorcowej oznaczono arsen w roztworach modelowych o stężeniach: 20,40 i $80 \mu \mathrm{g} / \mathrm{l}$, stosując zoptymalizowane dla matrycy parametry pomiarowe wynikające ze sposobu mineralizacji (z zastosowaniem kwasu azotowego(V), kwasu siarkowego(VI) i ditlenku diwodoru). Uzyskane wartości współczynnika zmienności CV wynoszą odpowiednio: 2,$18 ; 1,81$ i 2,10\%. Średni błąd względny wynosi odpowiednio: 1,70; 1,33 i 1,68\%.

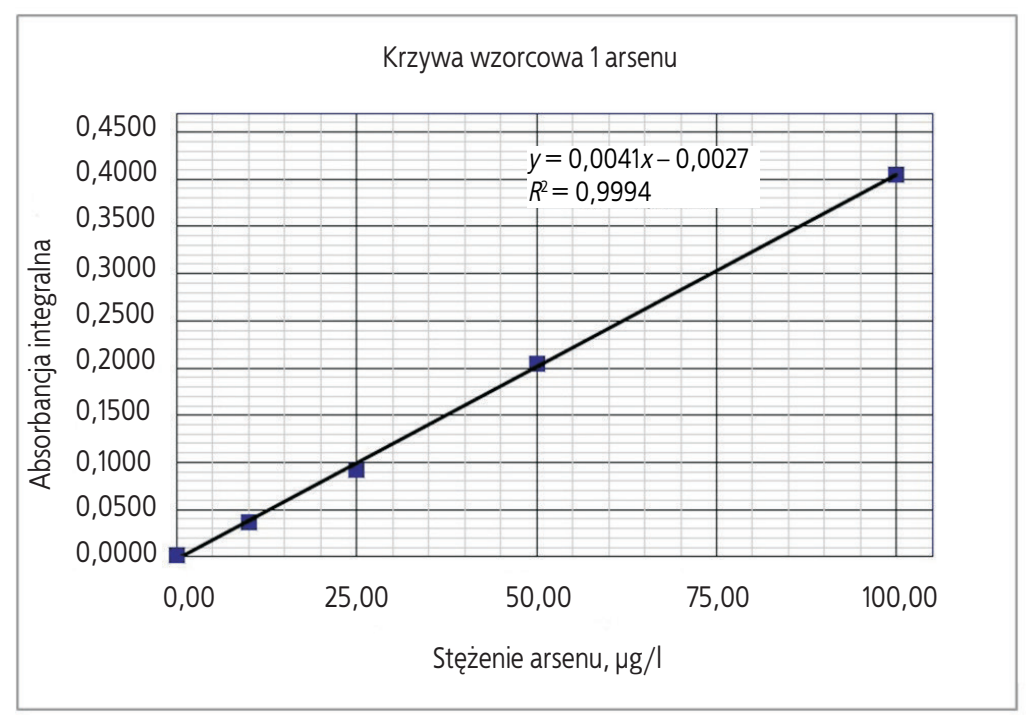

Ryc. 1. Krzywa wzorcowa oznaczania arsenu metodą ET-AAS w $\mathrm{HNO}_{3}$ o stężeniu $0,1 \mathrm{~mol} / \mathrm{l}$, przy długości fali 193,7 nm, $y=0,0041 x-0,0027 ; R=0,9997$

Fig. 1. Calibration curve for determining arsenic with ET-AAS method in $0.1 \mathrm{~mol} / \mathrm{I} \mathrm{HNO}_{3}$, at $193.7 \mathrm{~nm}, y=0.0041 x-0.0027 ; R=0.9997$ 


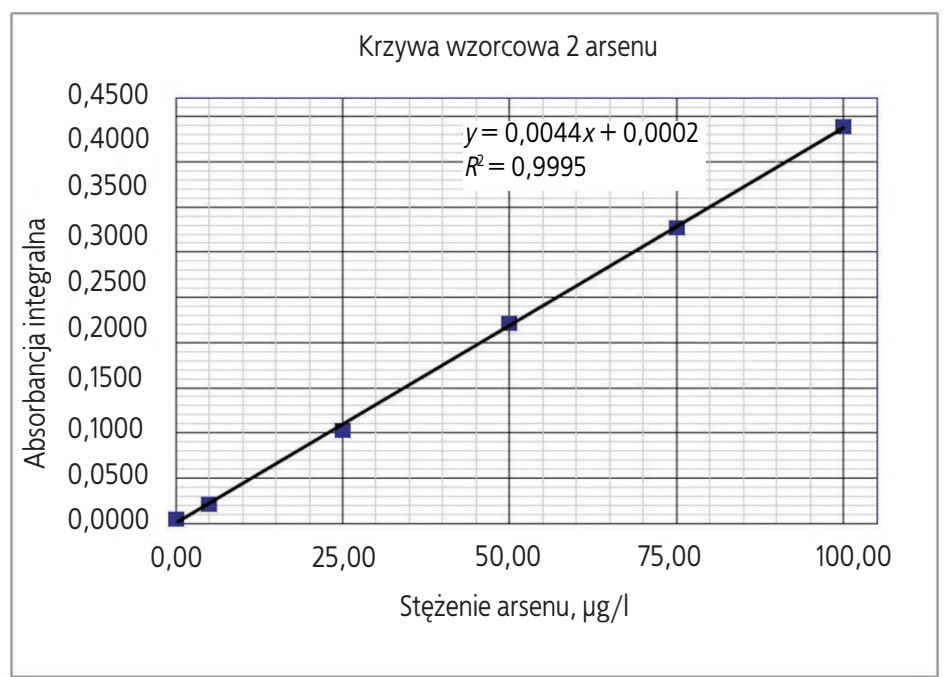

Ryc. 2. Krzywa wzorcowa oznaczania arsenu metodą ET-AAS w $\mathrm{HNO}_{3}$ o stężeniu 0,1 mol/li $\mathrm{H}_{2} \mathrm{SO}_{4}$ o stężeniu około 0,2 mol/l, przy długości fali 193,7 nm, $y=0,0044 x+0,0002 ; R=0,99975$

Fig. 2. Calibration curve for determining arsenic with ET-AAS method in $0.1 \mathrm{~mol} / \mathrm{I} \mathrm{HNO}_{3}$ and about $0.2 \mathrm{~mol} / \mathrm{l} \mathrm{H}_{2} \mathrm{SO}_{4}$, at $193.7 \mathrm{~nm}$, $y=0.0044 x+0.0002 ; R=0.99975$

Zakres pomiarowy: $5,00 \div 100,0 \mu \mathrm{g} / \mathrm{l}$ oznaczania arsenu $\mathrm{w}$ roztworze kwasu azotowego i siarkowego odpowiada zakresowi stężeń arsenu i jego związków (w przeliczeniu na arsen) w powietrzu: $0,0010 \div 0,021 \mathrm{mg} / \mathrm{m}^{3}$ (dla objętości próbki powietrza - $480 \mathrm{l}$, objętości analizowanego roztworu $10 \mathrm{ml}$ i krotności rozcieńczenia równej 10), co w odniesieniu do wartości NDS stanowi $0,1 \div 2$ tej wartości.

\section{Badanie wydajności mineralizacji}

Badania wydajności mineralizacji przedstawiono dla dwóch sposobów: mineralizacji filtra MCE oraz mineralizacji filtra MCE i impregnowanej węglanem sodu podkładki.

W celu określenia wydajności mineralizacji jako stopnia odzysku arsenu $\mathrm{z}$ filtra $\mathrm{z}$ estrów celulozy przeprowadzono następujące badania. $\mathrm{Na}$ przygotowane filtry membranowe umieszczone w zlewkach (po pięć próbek dla każdego poziomu stężeń) nanoszono po: 50, 100 i $200 \mu$ l roztworu arsenu o stężeniu $10 \mu \mathrm{g} / \mathrm{ml}$ i pozostawiano do wyschnięcia. Następnie do każdej zlewki dodawano po $3 \mathrm{ml}$ stężonego kwasu azotowego i $1 \mathrm{ml}$ ditlenku diwodoru, po czym bardzo ostrożnie ogrzewano na płycie grzejnej o temperaturze około $140^{\circ} \mathrm{C}$ do uwolnienia tlenków azotu i odparowania roztworu (prawie do sucha). Operacje powtarzano dwukrotnie. Następnie po ochłodzeniu zlewek dodawano do nich $1 \mathrm{ml}$ stężonego kwasu azotowego i po 30 min zawartość zlewek przenoszono ilościowo pięcioma lub sześcioma porcjami kwasu azotowego(V) o stężeniu $0,1 \mathrm{~mol} / \mathrm{l}$ do kolb o pojemności $25 \mathrm{ml}$ i uzupełniano do kreski roztworem kwasu azotowego(V) o stężeniu 0,1 mol/l. Uzyskano w ten sposób serię roztworów z zakresu krzywej wzorcowej o stężeniach arsenu: 20,0; 40,0 i 80,0 $\mu \mathrm{g} / \mathrm{l}$.

Równocześnie $\mathrm{w}$ identyczny sposób przygotowano roztwory po mineralizacji dwóch czystych filtrów do otrzymania w kolbie o pojemności $25 \mathrm{ml}$ roztworu próby ślepej. Roztwory porównawcze do badania stopnia odzysku przygotowano w identyczny sposób przez odmierzenie takich samych ilości roztworu wzorcowego podstawowego arsenu, jakie nanoszono na filtry, bezpośrednio do kolb o pojemności $25 \mathrm{ml}$ (dla każdego stężenia przygotowano po trzy roztwory porównawcze). Następnie dodawano kilka mililitrów roztworu kwasu azotowego o stężeniu $0,1 \mathrm{~mol} / \mathrm{l}$ i $1 \mathrm{ml}$ stężonego kwasu azotowego(V) i uzupełniano roztworem kwasu azotowego o stężeniu $1 \mathrm{~mol} / \mathrm{l}$.

Przy zastosowaniu podanego wyżej sposobu przygotowania próbki do oznaczania uzyskano bardzo dobry odzysk arsenu z filtra z estrów celulozy. Dla trzech poziomów stężeń arsenu: 20,0; 40,0 i $80,0 \mu \mathrm{g} / \mathrm{l}$ stopień odzysku wynosił odpowiednio: 0,$98 ; 0,98 ; 0,99$, a współczynnik zmienności CV - 1,69; 0,75 i 0,79\% (tab. 1.). 


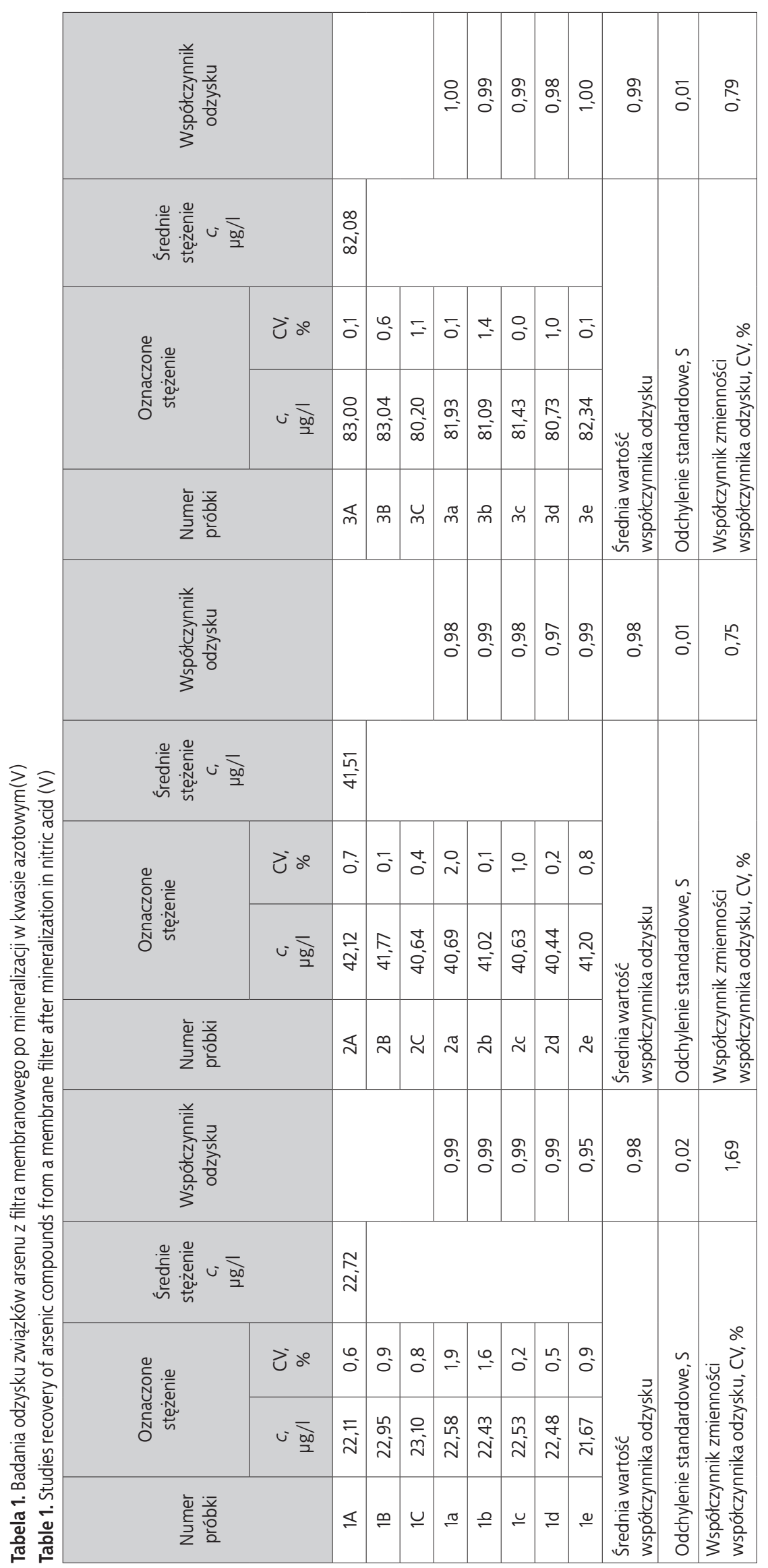




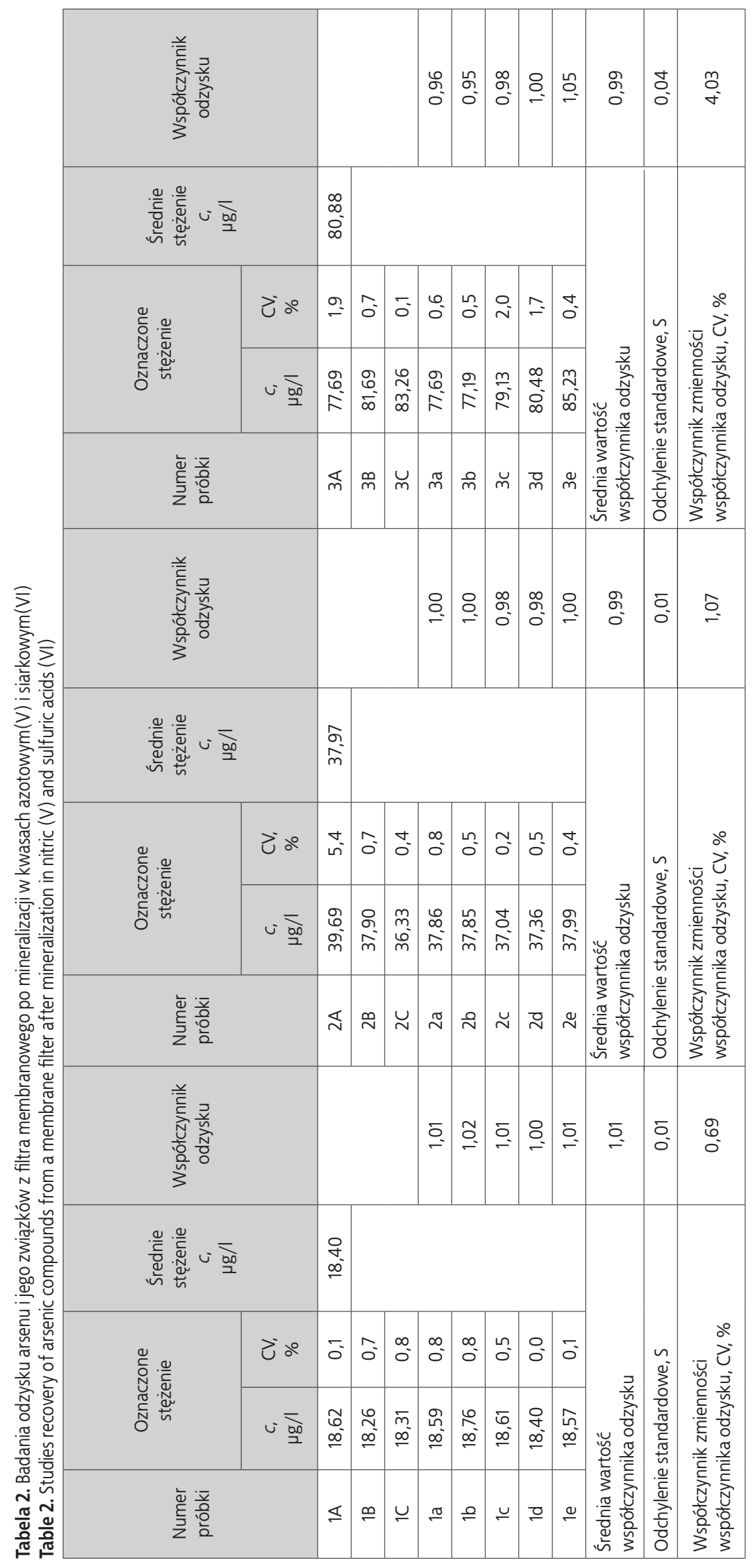


W celu określenia stopnia odzysku arsenu z filtra $\mathrm{z}$ estrów celulozy i celulozowej podkładki impregnowanej węglanem sodowym $\mathrm{w}$ roztworze gliceryny przeprowadzono następujące badania. Na przygotowane filtry membranowe umieszczone w zlewkach na impregnowanych podkładkach celulozowych (po pięć próbek dla każdego poziomu stężeń) nanoszono po 200; 400 i $800 \mu \mathrm{l} \mathrm{roz-}$ tworu arsenu o stężeniu $10 \mu \mathrm{g} / \mathrm{ml}$ i pozostawiano do wyschnięcia. Następnie do każdej zlewki dodawano po $5 \mathrm{ml}$ stężonego kwasu azotowego i $1 \mathrm{ml}$ kwasu siarkowego i ogrzewano ostrożnie na płycie grzejnej o temperaturze około $140^{\circ} \mathrm{C}$ aż do uwolnienia tlenków azotu. Następnie po ochłodzeniu zlewek dodawano do nich powoli $2 \mathrm{ml}$ ditlenku diwodoru i ostrożnie ogrzewano na płycie grzejnej o temperaturze około $140^{\circ} \mathrm{C}$ aż do uwolnienia się tlenu i uzyskania objętości $1 \mathrm{ml}$. Zawartość zlewek przenoszono ilościowo pięcioma lub sześcioma porcjami kwasu azotowego o stężeniu $0,1 \mathrm{~mol} / \mathrm{ldo}$ kolb o pojemności $25 \mathrm{ml}$ i uzupełniano do kreski roztworem kwasu azotowego o stężeniu $0,1 \mathrm{~mol} / \mathrm{l}$. Pobierano $2,5 \mathrm{ml}$ roztworu do kolby o pojemności $10 \mathrm{ml}$ i uzupełniano roztworem kwasu azotowego o stężeniu $0,1 \mathrm{~mol} / \mathrm{l}$, uzyskując w ten sposób serię roztworów z zakresu krzywej wzorcowej o stęże-

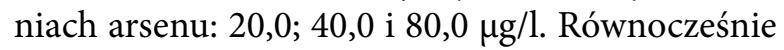
$\mathrm{w}$ identyczny sposób przygotowano roztwory po mineralizacji dwóch czystych filtrów, przez co uzyskano w kolbie o pojemności $25 \mathrm{ml}$ roztwór próby ślepej. Do analizy wykorzystywano ten roztwór po rozcieńczeniu: $2,5 \mathrm{ml}$ roztworu przenoszono do kolby o pojemności $10 \mathrm{ml}$ i uzupełniano kwasem azotowym o stężeniu $0,1 \mathrm{~mol} / \mathrm{l}$.

Roztwory porównawcze do badania stopnia odzysku przygotowano w identyczny sposób przez odmierzenie takich samych ilości roztworu wzorcowego podstawowego arsenu, jakie nanoszono na filtry, bezpośrednio do kolb o pojemności $25 \mathrm{ml}$ (dla każdego stężenia przygotowano po trzy roztwory porównawcze), po czym uzupełniano roztworem kwasu azotowego o stężeniu $1 \mathrm{~mol} / \mathrm{l}$. Następnie rozcieńczano próbkę: pobierano 2,5 $\mathrm{ml}$ uzyskanego roztworu do kolby o pojemności $10 \mathrm{ml}$, dodawano $2,5 \mathrm{ml}$ nierozcieńczonego roztworu próbki ślepej (z kolby o pojemności $25 \mathrm{ml}$ ) i uzupełniano roztworem kwasu azotowego o stężeniu $0,1 \mathrm{~mol} / \mathrm{l}$ do pojemności $10 \mathrm{ml}$.

Roztwory analizowano metodą absorpcyjnej spektrometrii atomowej $\mathrm{z}$ atomizacją $\mathrm{w}$ kuwecie grafitowej. Mierzono stężenie arsenu w roztworach przygotowanych po mineralizacji oraz $\mathrm{w}$ roztworze przygotowanym równolegle $\mathrm{z}$ czystego filtra i podkładki celulozowej po mineralizacji - roztwór do ślepej próby - kontrolny. Wartość stężenia próby ślepej odejmowano od wyniku oznaczenia. Mierzono stężenie arsenu w przygotowanych roztworach oraz $\mathrm{w}$ roztworze przygotowanym równolegle z czystego filtra i celulozowej podkładki po mineralizacji - roztworze do ślepej próby - roztworze kontrolnym. Wyniki badań stopnia odzysku $\mathrm{z}$ zastosowaniem tego sposobu mineralizacji zamieszczono w tabeli 2.

Po zastosowaniu do mineralizacji filtra nitrocelulozowego wraz z impregnowaną podkładką celulozową stężonego kwasu azotowego(V) i kwasu siarkowego(VI) oraz ditlenku diwodoru i przygotowaniu próbki do oznaczania również uzyskano dobry odzysk arsenu. Dla trzech poziomów stężeń arsenu: 20,0; 40,0 i 80,0 $\mu \mathrm{g} / \mathrm{l}$ stopień odzysku wynosił odpowiednio: 1,$01 ; 0,99$ i 0,99, a współczynnik zmienności CV wynosił - 0,69; 1,07 i 4,03\%.

\section{Wyznaczanie granicy oznaczania ilościowego}

W celu wyznaczenia granicy oznaczania ilościowego przygotowano próbkę zerową o stężeniu kwasu azotowego $0,1 \mathrm{~mol} / \mathrm{l}$, nie zawierającą arsenu. Wykonano dziesięciokrotny pomiar absorbancji integralnej roztworu i uzyskano wyniki: 0,0002 ; 0,$0001 ; 0,0001 ; 0,0001 ; 0,0000 ; 0,0003 ; 0,0000$; 0,$0001 ; 0,0002$ i 0,0001 . Wyznaczono odchylenie standardowe absorbancji SD wynoszące 0,0003. Wyznaczona masa charakterystyczna $\left(m_{c h}\right)$ arsenu w opracowanej metodzie wynosiła: 20,1 pg.

Granicę wykrywalności wyznaczono według wzoru:

$$
\mathrm{LOD}=\frac{3 \cdot \mathrm{SD} \cdot m_{c h}}{0,0044}
$$

Obliczona granica wykrywalności wyniosła 4,1 pg. Granica oznaczania ilościowego LOQ, w opracowanej metodzie wyznaczona na poziomie $\sigma=3$, wyniosła $12,3 \mathrm{pg}$.

Granicę wykrywalności arsenu w roztworze zawierającym kwas siarkowy wyznaczono na podstawie pomiarów próbki zerowej przygotowanej $\mathrm{z}$ roztworu po mineralizacji i rozcieńczonej w sposób identyczny jak próbki do analizy. Wykonano dziesięciokrotny pomiar absorbancji integral- 
nej roztworu i uzyskano wyniki: 0,$0020 ; 0,0021$; 0,$0011 ; 0,0015 ; 0,0008 ; 0,0019 ; 0,0015 ; 0,0011$; 0,0019 i 0,0022 . Wyznaczono odchylenie standardowe absorbancji SD wynoszące 0,0005. Masa charakterystyczna $\left(m_{c h}\right)$ arsenu w tej metodzie wynosiła $22 \mathrm{pg}$. Obliczona według wzoru granica wykrywalności wyniosła 7,5 pg. Wyznaczona granica oznaczalności (LOQ) arsenu (na poziomie $\sigma=3$ ) wyniosła w tym przypadku 22,5 pg.

\section{Wpływ substancji towarzyszących}

Przeprowadzono badania mające na celu sprawdzenie, czy obecność substancji współwystępujących ma wpływ na wynik oznaczania arsenu w przyjętych warunkach. Badania przeprowadzono dla tych czynników, które jak wynika z przeprowadzonego rozpoznania, mogą występować wraz $\mathrm{z}$ arsenem $\mathrm{w}$ różnych procesach technologicznych. W tym celu przygotowano roztwory próbek zawierające oprócz arsenu inne pierwiastki w analizowanej próbce. W wyniku przeprowadzonych badań stwierdzono, że obecność pierwiastków Zn, $\mathrm{Cu}, \mathrm{Pb}, \mathrm{Sb}, \mathrm{Ni}$ i Cd w badanej próbce w zakresie stężeń $10 \div 50 \mu \mathrm{g} / \mathrm{l}$ niezależnie od zastosowanej metody mineralizacji i atomizacji próbki nie wpływa na wynik oznaczenia arsenu metodą ET-AAS.

\section{Walidacja}

Walidację metody przeprowadzono zgodnie z wymaganiami normy europejskiej PN-EN 482 i PN-EN ISO 21832:2020-10. W budżecie niepewności oznaczania arsenu i jego nieorganicznych związków w powietrzu na stanowiskach pracy uwzględniono składowe niepewności losowe i nielosowe związane $\mathrm{z}$ etapem pobierania próbek i etapem badań laboratoryjnych wg norm PN-EN 482 i PN-EN ISO 21832:2020-10.

Względną niepewność złożoną oznaczania arsenu i jego związków nieorganicznych $u_{\text {crel }}$ obliczono wg wzoru

$$
u_{\text {crel }}=\sqrt{u_{\text {rel } 1}^{2}+u_{\text {rel } 2}^{2} \cdots+u_{\text {rel } n}^{2}},
$$

w którym:

$u_{\text {rel }(1, \ldots, n)}$ - względne niepewności wszystkich składowych niepewności wyznaczonych w budżecie niepewności.

Jako składowe niepewności $\mathrm{w}$ etapie pobierania próbek powietrza uwzględniono względne niepewności związane z: niepewnością przepływomierza, niepewnością odczytu przepływu, niepewnością związaną ze stabilnością aspiratora, niepewnością czasu pobierania próbki oraz niepewnością związaną z próbnikiem do pobierania frakcji wdychalnej i efektywnością pobierania tej frakcji, a także niepewnością związaną z transportem próbek. Niepewność związaną z etapem badań laboratoryjnych wyznaczono jako sumę składowych: niepewności funkcji kalibracji i oznaczania arsenu oraz odzysku $\mathrm{z}$ filtra wyrażone jako względne odchylenie standardowe, niepewności stosowanego wzorca arsenu, niepewności objętości pipet jednomiarowych i automatycznych i kolb miarowych oraz niepewności związanej z rozcieńczaniem próbek. Uwzględniono również niepewność dryfu sygnału spektrometru (Dobecki 2012).

Względną niepewność rozszerzoną ( $U$, w procentach) oznaczania arsenu i jego związków nieorganicznych obliczono dla poziomu ufności $p=0,95$ i współczynnika rozszerzenia $k_{p}=2$ na podstawie wzoru:

$$
U=k_{p} \cdot u_{\text {crel }} \cdot
$$

Na podstawie wyników przeprowadzonych badań uzyskano następujące dane $\mathrm{z}$ walidacji metody oznaczania arsenu w próbce zawierającej różne matryce:

Oznaczanie arsenu metodą ET-AAS w roztworze rozcieńczonego kwasu azotowego:

- zakres pomiarowy: $10,00 \div 100,0 \mu \mathrm{g} / \mathrm{l}$

- krzywa wzorcowa: $y=0,0041 x-0,0027$

- kwadrat współczynnika korelacji, $R^{2}=0,9994$

- granica wykrywalności (LOD) - 4,1 pg

- granica oznaczalności (LOQ) - 12,3 pg

- zakres pomiarowy $\mathrm{w}$ powietrzu arsenu i jego nieorganicznych związków we frakcji wdychalnej aerozolu: $0,001 \div 0,010 \mathrm{mg} /$ $\mathrm{m}^{3}$ dla próbki powietrza $240 \mathrm{l}$

- względna niepewność złożona pobierania próbki powietrza do oznaczania arsenu i jego związków wynosi 9,46\% (240 min, $480 \mathrm{l}$ przy przepływie $2 \mathrm{l} / \mathrm{min}$ )

- względna niepewność złożona etapu analitycznego oznaczania arsenu i jego związków metodą ET-AAS wynosi $4,52 \%$

- względna niepewność złożona oznaczania arsenu i jego nieorganicznych związków wynosi $10,49 \%$ 
- względna niepewność rozszerzona oznaczania arsenu i jego nieorganicznych związków wynosi 20,98\%.

Oznaczanie arsenu metodą ET-AAS w roztworze rozcieńczonego kwasu azotowego i kwasu siarkowego:

- zakres pomiarowy: $5,00 \div 100,0 \mu \mathrm{g} / \mathrm{l}$

- krzywa wzorcowa: $y=0,0044 x+0,0002$

- kwadrat współczynnika korelacji, $R^{2}=0,9995$

- granica wykrywalności (LOD) - 7,5 pg

- granica oznaczalności (LOQ) - 22,5 pg

- zakres pomiarowy $\mathrm{w}$ powietrzu arsenu i jego związków nieorganicznych we frakcji wdychalnej aerozolu: 0,0010 $\div$ $0,021 \mathrm{mg} / \mathrm{m}^{3}$ dla próbki powietrza 4801 i krotności rozcieńczenia analizowanej próbki równej 10

- względna niepewność złożona pobierania próbki powietrza do oznaczania arsenu i jego związków wynosi 9,46\% (240 min, $480 \mathrm{l}$ przy przepływie $2 \mathrm{l} / \mathrm{min}$ )

- względna niepewność złożona etapu analitycznego oznaczania arsenu i jego związków metodą ET-AAS wynosi 4,83\%

- względna niepewność złożona oznaczania arsenu i jego nieorganicznych związków wynosi $10,62 \%$

- względna niepewność rozszerzona oznaczania arsenu i jego nieorganicznych związków wynosi 21,24\%.

\section{PODSUMOWANIE}

Opracowano metodę oznaczania arsenu i jego nieorganicznych związków umożliwiającą uzyskanie wymaganej granicy oznaczalności równej 1/10 wartości NDS. Metoda polega na zatrzymaniu na filtrze membranowym arsenu i jego związków nieorganicznych zawartych w powietrzu na stanowiskach pracy, mineralizacji filtra i oznaczaniu tych związków jako arsen metodą absorpcyjnej spektrometrii atomowej $\mathrm{z}$ elektrotermiczną atomizacją (ET-AAS) i korekcją tła metodą Zeemana. Arsen oznacza się przy długości fali 193,7 nm, w kuwecie grafitowej przeznaczonej do oznaczania pierwiastków łatwo lotnych, stosując temperaturę spopielania próbki $1100^{\circ} \mathrm{C}$ i temperaturę atomizacji $2300^{\circ} \mathrm{C}$.

Zakres pomiarowy $10,00 \div 100,0 \mu \mathrm{g} / \mathrm{l}$ oznaczania arsenu $\mathrm{w}$ roztworze rozcieńczonego kwasu azotowego odpowiada zakresowi stężeń arsenu i jego związków nieorganicznych (w przeliczeniu na arsen) w powietrzu $0,001 \div 0,010 \mathrm{mg} / \mathrm{m}^{3}$ (dla objętości analizowanego roztworu po mineralizacji - $25 \mathrm{ml}$, objętości próbki powietrza - $240 \mathrm{llub}$ $50 \mathrm{ml}$ analizowanego roztworu i objętości próbki powietrza - 480 l), co w odniesieniu do wartości NDS stanowi $0,1 \div 1$ tej wartości. Uzyskanie wymaganej oznaczalności dla małej objętości pobieranego powietrza jest korzystne szczególnie w przypadku dużej ilości aerozolu w środowisku pracy i dużego obciążenia filtra. Możliwe jest wtedy pobranie, w ramach zmiany roboczej, trzech, a nawet czterech próbek i zastosowanie opracowanej metody do oznaczania arsenu.

Metoda umożliwia wykrywanie i ilościowe oznaczanie $\mathrm{w}$ powietrzu na stanowiskach pracy bardzo niskich stężeń arsenu. Dla objętości próbki powietrza 4801 najmniejsze stężenie arsenu i jego związków, jakie można oznaczyć opracowaną metodą, wynosi $0,0005 \mathrm{mg} / \mathrm{m}^{3}$. W przypadku bardzo małych stężeń arsenu i jego związków nieorganicznych zawartych w powietrzu w postaci aerozolu można pobrać większą próbkę powietrza, np. o objętości 720 l, i oznaczać w powietrzu tę rakotwórczą substancję na poziomie nawet $0,00035 \mathrm{mg} / \mathrm{m}^{3}$.

Jeżeli w badanym powietrzu oprócz aerozolu mogą występować związki arsenu w postaci lotnej takie jak tritlenek arsenu (ciało stałe, które sublimuje w temp. $193^{\circ} \mathrm{C}$ ), można zastosować metodę pobierania próbki polegającą na ich zatrzymaniu na filtrze membranowym $z$ estrów celulozy wraz z podkładką celulozową impregnowaną roztworem węglanu sodu. Filtr i podkładkę mineralizuje się na gorąco $\mathrm{w}$ stężonym kwasie azotowym(V) i kwasie siarkowym(VI) z dodatkiem ditlenku diwodoru. Arsen oznacza się w otrzymanym roztworze również metodą ET-AAS z korekcją tła metodą Zeemana, przy długości fali 193,7 nm, $\mathrm{z}$ zastosowaniem zmodyfikowanego programu temperaturowego - temperatura spopielania $700^{\circ} \mathrm{C}$ i temperatura atomizacji $2300^{\circ} \mathrm{C}$. 
Zakres pomiarowy $5,00 \div 100,0 \mu \mathrm{g} / \mathrm{l}$ oznaczania arsenu w roztworze rozcieńczonego kwasu azotowego i kwasu siarkowego odpowiada zakresowi stężeń arsenu i jego związków nieorganicznych (w przeliczeniu na arsen) w powietrzu 0,0010 $\div$ $0,021 \mathrm{mg} / \mathrm{m}^{3}$ (dla objętości analizowanego roztworu po mineralizacji - $25 \mathrm{ml}$, objętości próbki powietrza - 4801 i krotności rozcieńczenia próbki 10), co w odniesieniu do wartości NDS stanowi $0,1 \div 2$ tej wartości.

Przedstawionej metody nie można stosować do oznaczania arsenowodoru (arsanu).

Przeprowadzone badania odzysku arsenu z filtra, sprawdzające zastosowane sposoby mineralizacji: $\mathrm{z}$ użyciem kwasu azotowego(V) i ditlen$\mathrm{ku}$ diwodoru oraz kwasu azotowego(V), kwasu siarkowego(VI) i ditlenku diwodoru, na trzech poziomach stężeń arsenu i wyznaczenie średniego współczynnika odzysku wynoszącego odpowiednio dla tych sposobów mineralizacji: 0,98 i 1,0 potwierdziły pełną mineralizację próbki.

Obliczona na podstawie niepewności względnych niepewność złożona etapu pobierania próbki powietrza wyniosła $9,46 \%$, niepewność złożona etapu analitycznego oznaczania arsenu i jego związków nieorganicznych $\mathrm{z}$ użyciem do mineralizacji kwasu azotowego wyniosła 4,52\%, a niepewność złożona etapu analitycznego oznaczania arsenu i jego związków nieorganicznych z użyciem do mineralizacji kwasu azotowego i siarkowego wyniosła $4,83 \%$.

Niepewność złożona oznaczania arsenu i jego związków nieorganicznych z zastosowaniem ET-AAS dla dwóch sposobów pobierania próbki i jej mineralizacji wyniosła: 10,49 i $10,62 \%$, a niepewność rozszerzona oznaczania - 20,98 i 21,24\%.

Wyznaczona niepewność rozszerzona dla obu sposobów analitycznych spełnia wymagania normy PN-EN 482. Uzyskane parametry walidacyjne klasyfikują opracowaną metodę jako przydatną do pomiarów szkodliwych substancji chemicznych zawartych $\mathrm{w}$ powietrzu na stanowiskach pracy i metoda może być stosowana do oceny narażenia zawodowego na arsen i jego związki nieorganiczne występujące w powietrzu na stanowiskach pracy.

Metoda oznaczania arsenu i jego związków nieorganicznych z zastosowaniem ET-AAS jest dostosowana do wykonywania pomiarów stężeń arsenu i jego związków na stanowiskach pracy zgodnie $\mathrm{z}$ zasadami dozymetrii indywidualnej i umożliwia przeprowadzenie oceny narażenia zawodowego zgodnie z normą PN-Z-04008-7/Az1:2004.

Opracowaną metodę oznaczania arsenu i jego związków nieorganicznych, w tym tritlenku arsenu, zapisano $\mathrm{w}$ formie procedury analitycznej, którą zamieszczono w załączniku.

\section{PIŚMIENNICTWO}

ATSDR (2016). Agency for toxic substances and disease registry. Addendum to the toxicological profile for arsenic [https:// www.atsdr.cdc.gov/ToxProfiles/tp2-c4.pdf, https://wwwn. cdc.gov/TSP/ToxProfiles/ToxProfiles.aspx?id=22\&tid=3, https://www.atsdr.cdc.gov/ToxProfiles/tp2-c7.pdf, data dostępu: 25.02.2021]

BIA (1989). Berufsgenossenschaftliches Institut für Arbeitssicherhei. Arsen. Method BIA 6195-1 Sankt Augustin [https:// amcaw.ifa.dguv.de/substance/methoden/079-L-Arsenic.pdf, data dostępu: 25.02.2021].

BIA (1990). Berufsgenossenschaftliches Institut für Arbeitssicherhei. Arsen. Method BIA 6195-2 Sankt Augustin [https:// amcaw.ifa.dguv.de/substance/methoden/079-L-Arsenic.pdf, data dostępu: 8.02.2021].

Dobecki M. (2012). Walidacja metod pomiarowych i szacowanie niepewności pomiaru czynników chemicznych w powietrzu na stanowiskach pracy [Validation of measurement methods and estimation of uncertainty of measurement of chemical agents in the air at workstations]. Med. Pr. 63(6), 723-732.

ECHA (2021a). European Chemicals Agency. Arsenic [https:// echa.europa.eu/pl/information-on-chemicals/cl-inventory-database/-/discli/details/85010, data dostępu: 25.02.2021].

ECHA (2021b). European Chemicals Agency. Arsenic trioxide [https:/echa.europa.eu/pl/information-on-chemicals/ cl-inventory-database/-/discli/details/112594, data dostępu: 25.02.2021].

GESTIS (2021a). Substance database. BG Institute for Occupational Safety and Health, Sankt Augustin, Germany. Arsenic [https://gestis-database.dguv.de/data?name $=008280$, data dostępu: 25.02.2021].

GESTIS (2021b). Substance database. BG Institute for Occupational Safety and Health, Sankt Augustin, Germany. Arsenic acid [https://gestis-database.dguv.de/data?name=500006, data dostępu: 25.02.2021]. 
GESTIS (2021c). Substance database. BG Institute for Occupational Safety and Health, Sankt Augustin, Germany. Diarsenic trioxide [https://gestis-database.dguv.de/data? name $=002100$, data dostępu: 25.02.2021].

HSDB (2018). Hazardous Substances Data Bank. U.S. National Library of Medicine (NLM) Toxicology Data Network (TOXNET). USA

ISO 11041:1996 Workplace air - Determination of particulate arsenic and arsenic compounds and arsenic trioxide vapour - Method by hydride generation and atomic absorption spectrometry.

Jakubowski M. (2000). Arsen i jego nieorganiczne związki (w przeliczeniu na As). Dokumentacja proponowanych wartości dopuszczalnych poziomów narażenia zawodowego [Arsenic and its inorganic compounds (as As). Documentation of proposed values of occupational exposure limits (OELs)]. Podst. Metod. Ocen. Środ. Pr. 1(23), 23-55.

Kulik-Kupka K., Koszowska A., Bończyk-Puzon A., Nowak J., Gwizdek J., Zubelewicz-Szkodzińska B. (2016). Arsen - trucizna czy lek? [Arsenic - poison or medicine?]. Med. Pr. 67(1), 89-96.

ILO (2008). International Labour Organization. Trioxyde d'arsenic ICSC: 0378. (C) version en français, INRS, 2018 [https://www.ilo.org/dyn/icsc/showcard.display?p_lang=fr\&p_card_id=0378\&p_version=2, data dostępu: 8.02.2021].

MDHS (1995). Methods for the Determination of Hazardous Substances. Arsenic and inorganic compounds of arsenic (except arsine) in air. MDHS 41/2. Health and Safety Executive.

NIOSH (1994a). National Institute of Occupational Safety and Health. Manual of Analytical Methods (NMAM). Arsenic and compounds as As (except $\mathrm{AsH}_{3}$ and $\mathrm{As}_{2} \mathrm{O}_{3}$ ). Method 7900, Salt Lake City [https://www.cdc.gov/niosh/docs/2003154/pdfs/7900.pdf, data dostępu: 25.02.2021].

NIOSH (1994b). National Institute of Occupational Safety and Health. Manual of Analytical Methods (NMAM). Arsenic trioxide as As. Method 7901, Salt Lake City [https:// www.cdc.gov/niosh/docs/2003-154/pdfs/7901.pdf, data dostepu: 25.02.2021].

NIOSH (1994c). National Institute of Occupational Safety and Health. Manual of Analytical Methods (NMAM). Arsine. Method 6001, Salt Lake City [https://www.cdc.gov/niosh/ docs/2003-154/pdfs/6001.pdf, data dostępu: 25.02.2021].

NIOSH (2003a). National Institute of Occupational Safety and Health. Manual of Analytical Methods (NMAM). Elements by ICP (Nitric/Perchloric Acid Ashing). Method 7300, Salt Lake City [https://www.cdc.gov/niosh/docs/2003-154/ pdfs/7300.pdf, data dostępu: 25.02.2021]

NIOSH (2003b). National Institute of Occupational Safety and Health. Manual of Analytical Methods (NMAM). Elements by ICP (Aqua Regia Ashing). Method 7301, Salt Lake City [https://www.cdc.gov/niosh/docs/2003-154/pdfs/7301. pdf, data dostępu: 25.02.2021].

NIOSH (2003c). National Institute of Occupational Safety and Health. Manual of Analytical Methods (NMAM).
Elements by ICP (Hot Block/HCl/HNO3 Digestion). Method 7303, Salt Lake City [https://www.cdc.gov/niosh/docs/2003154/pdfs/7303.pdf, data dostępu: 25.02.2021].

NIOSH (2014a). National Institute of Occupational Safety and Health. Manual of Analytical Methods (NMAM). Elements by ICP (Microwave Digestion). Method 7302, Salt Lake City [https://www.cdc.gov/niosh/docs/2003-154/pdfs/7302. pdf, data dostępu: 25.02.2021].

NIOSH (2014b). National Institute of Occupational Safety and Health. Manual of Analytical Methods (NMAM). Elements by ICP (Microwave Digestion). Method 7304, Salt Lake City [https://www.cdc.gov/niosh/docs/2003-154/pdfs/7304. pdf, data dostępu: 25.02.2021].

NIOSH (2015a). National Institute of Occupational Safety and Health. Manual of Analytical Methods (NMAM). Elements by Cellulosic Internal Capsule Sampler. Method 7306, Salt Lake City [https://www.cdc.gov/niosh/docs/2014-151/ pdfs/methods/7306.pdf, data dostępu: 25.02.2021].

NIOSH (2015b). National Institute of Occupational Safety and Health. Manual of Analytical Methods (NMAM). Arsine. Method 6001, Salt Lake City [https://www.cdc.gov/ niosh/docs/2014-151/pdfs/methods/6001.pdf, data dostępu: 25.02.2021].

OSHA (1991). Occupational Safety and Health Administration. Method ID-105 and method ID-105 backup. Inorganic arsenic in workplace air. Division of Physical Measurements and Inorganic Analyses, OSHA Technical Center, Salt Lake City, Utah [http://www.mdcampbell.com/niosh/oshameth/id105/id105. htm, data dostępu: 25.02.2021]

OSHA (2005). Occupational Safety and Health Administration. Method 1006. Arsenic, cadmium, cobalt, copper, lead, and nickel (open vessel microwave digestion/ICP-MS analysis). Industrial Hygiene Chemistry Division, OSHA Salt Lake Technical Center, Sandy, Utah [https://www.osha.gov/ sites/default/files/methods/osha-1006.pdf, data dostępu: 25.02.2021].

OSHA (2019). Occupational Safety and Health Administration. Method 5003. Metal sampling group 1 (METALSSG-1). Metals collected on mixed cellulose ester filter. Method Development Team, Industrial Hygiene Chemistry Division, OSHA Salt Lake Technical Center, Sandy, Utah [https://www. osha.gov/sites/default/files/methods/OSHA\%205003.pdf, data dostępu: 25.02.2021].

Patnaik P. (2002). Handbook of inorganic chemicals. New York, McGraw-Hill. 836-842.

PN-EN 482+A1:2016 Narażenie na stanowiskach pracy - Wymagania ogólne dotyczące charakterystyki procedur pomia- rów czynników chemicznych [Workplace exposure - General requirements for the performance of procedures for the meas- urement of chemical agents].

PN-EN ISO 21832:2020-10 - wersja angielska. Powietrze na stanowiskach pracy - Metale i metaloidy w cząstkach zawieszonych w powietrzu - Wymagania dotyczące oceny procedur pomiarowych [Workplace air - Metals and metalloids in 
airborne particles - Requirements for evaluation of measuring procedures].

PN-Z-04008-7:2002/Az1:2004 Ochrona czystości powietrza Pobieranie próbek - Zasady pobierania próbek powietrza na stanowiskach pracy i interpretacji wyników [Polish standard].

PN-Z-04011-8:2004 Ochrona czystości powietrza - Badania zawartości arsenu i jego związków - Część 8: Oznaczanie arsenu i jego związków na stanowiskach pracy metodą wodorkową absorpcyjnej spektrometrii atomowej [Polish standard].

PubChem (2021a). Database. Arsenic (compound). National Center for Biotechnology Information (NCBI). USA, U.S. National Library of Medicine, United States National Institutes of Health (NIH) [https://pubchem.ncbi.nlm.nih.gov/compound/Arsenic, data dostępu: 25.02.2021].

PubChem (2021b). Database. Trisenox. National Center for Biotechnology Information (NCBI). USA, U.S. National Library of Medicine, United States National Institutes of Health (NIH) [https://pubchem.ncbi.nlm.nih.gov/compound/14888/Trisenox, data dostępu: 25.02.2021].

Rozporządzenie Ministra Rodziny, Pracy i Polityki Społecznej z dnia 12 czerwca 2018 r. w sprawie najwyższych dopuszczalnych stężeń i natężeń czynników szkodliwych dla zdrowia w środowisku pracy. Dz.U. 2018 poz. 1286 wraz z późn. zm. Dz.U. 2020 poz. 61 [Polish legal act].
Rozporządzenie Parlamentu Europejskiego i Rady (WE) nr 1272/2008 z dnia 16 grudnia 2008 r. w sprawie klasyfikacji, oznakowania i pakowania substancji i mieszanin, zmieniającego i uchylającego dyrektywy 67/548/EWG i 1999/45/WE oraz zmieniającego rozporządzenie (WE) nr 1907/2006 zwanego rozporządzeniem GHS). Dz. Urz. UE z dnia 31.12.2008 r. (L 353) [Regulation (EC) No 1272/2008 of the European Parliament and of the Council of 16 December 2008 on classification, labelling and packaging of substances and mixtures, amending and repealing Directives 67/548/EEC and 1999/45/EC, and amending Regulation (EC) No 1907/2006. OJEU L 353].

Sińczuk-Walczak H. (2009). Zmiany w układzie nerwowym w następstwie narażenia zawodowego na arsen i związki nieorganiczne arsenu w świetle piśmiennictwa [Nervous system disorders induced by occupational exposure to arsenic and its inorganic compounds: a literature review]. Med. Pr. 60(6), 519-522.

Sitarek K., Szadkowska-Stańczyk I., Szymczak W. (2003). Arsen i nieorganiczne związki arsenu [Arsenic and its inorganic compounds]. Wytyczne szacowania ryzyka zdrowotnego dla czynników rakotwórczych. Tom 17. Łódź, IMP.

SKC (1992). Operating instructions. Preloaded coated filters Cat. No. 225-9001 [https://www.skcltd.com/images/ pdfs/40030.pdf, data dostępu: 25.02.2021]. 



\section{PROCEDURA ANALITYCZNA OZNACZANIA ARSENU I JEGO ZWIAZZKÓW NIEORGANICZNYCH W POWIETRZU NA STANOWISKACH PRACY}

\section{Zakres stosowania metody}

W niniejszej procedurze podano metodę oznaczania arsenu (CAS: 744-38-2) i jego związków nieorganicznych w powietrzu na stanowiskach pracy z zastosowaniem absorpcyjnej spektrometrii atomowej z kuwetą grafitową. Metodę stosuje się podczas kontroli warunków sanitarnohigienicznych.

Najmniejsze stężenie arsenu i jego związków nieorganicznych, w tym tritlenku diarsenu, we frakcji wdychalnej, jakie można oznaczać w warunkach pobierania próbek powietrza i wykonania oznaczania opisanych $\mathrm{w}$ normie, wynosi $0,001 \mathrm{mg} / \mathrm{m}^{3}$ (dla próbki powietrza o objętości $480 \mathrm{l}$ ).

Metody nie stosuje się do oznaczania arsanu (arsenowodoru).

\section{Normy związane}

Do stosowania niniejszego dokumentu są niezbędne podane niżej dokumenty, które w całości lub $\mathrm{w}$ części zostały $\mathrm{w}$ nim normatywnie powołane. W przypadku powołań datowanych ma zastosowanie wyłącznie wydanie cytowane. W przypadku powołań niedatowanych stosuje się ostatnie wydanie dokumentu powołanego (łącznie ze zmianami).

PN-Z-04008-7 Ochrona czystości powietrza Pobieranie próbek - Zasady pobierania próbek powietrza w środowisku pracy i interpretacji wyników.

\section{Zasada metody}

Znaną objętość badanego powietrza przepuszcza się przez filtr membranowy i podkładkę celulozową zaimpregnowaną roztworem węglanu sodu $\mathrm{w}$ glicerynie, umieszczone $\mathrm{w}$ próbniku w celu osadzenia na nich arsenu i jego związków nieorganicznych, $w$ tym tritlenku diarsenu, zawartych we frakcji wdychalnej aerozolu. Próbkę mineralizuje się $\mathrm{w}$ kwasie azotowym(V) i kwasie siarkowym(VI) z dodatkiem ditlenku diwodoru. Arsen i jego związki nieorganiczne oznacza się jako arsen $\mathrm{w}$ roztworze sporządzonym do analizy metodą absorpcyjnej spektrometrii atomowej $\mathrm{w}$ kuwecie grafitowej.

\section{Wytyczne ogólne}

\subsection{Dokładność ważenia}

O ile nie zaznaczono inaczej, substancje stosowane $\mathrm{w}$ analizie należy ważyć $\mathrm{z}$ dokładnością do $0,0002 \mathrm{~g}$.

4.2. Czystość szkła

W analizie należy używać wyłącznie naczyń laboratoryjnych ze szkła boro-krzemowego lub z polietylenu. Naczynia należy myć kolejno roztworem detergentu, ciepłą wodą, roztworem kwasu azotowego(V) o stężeniu $1 \mathrm{~mol} / \mathrm{l}$ i wodą destylowaną, a następnie kilkakrotnie płukać wodą dwukrotnie destylowaną lub dejonizowaną.

4.3. Postępowanie z substancjami niebezpiecznymi

Czynności, podczas których używa się stężonych kwasów, należy wykonywać z użyciem środków ochrony indywidualnej, pod sprawnie działającym wyciągiem laboratoryjnym.

Pozostałe po analizie substancje i roztwory należy gromadzić w przeznaczonych do tego celu pojemnikach i przekazywać do utylizacji w uprawnionych instytucjach.

\section{Odczynniki, roztwory i materiały}

Podczas analizy, jeśli nie ma innych wymagań, należy stosować substancje o stopniu czystości co najmniej cz.d.a., a do przygotowywania wszystkich roztworów należy stosować wodę dwukrotnie destylowaną lub dejonizowaną, zwaną $\mathrm{w}$ dalszej treści procedury wodą.

5.1. Argon sprężony

Stosować argon sprężony N 5.0 o stopniu czystości - analizowany czysty lub wg instrukcji do aparatu.

5.2. Kwas azotowy(V), stężony, o ułamku masowym $65 \%$, o gęstości $1,39 \mathrm{~g} / \mathrm{ml}$

5.3. Kwas azotowy(V), roztwór o stężeniu $0,1 \mathrm{~mol} / 1$

5.4. Kwas siarkowy(VI), stężony, o ułamku masowym $96 \%$, o gęstości $1,84 \mathrm{~g} / \mathrm{ml}$

5.5. Ditlenek diwodoru

Stosować roztwór o ułamku masowym $30 \%$.

5.6. Gliceryna

Stosować roztwór o ułamku masowym $\geq 99,5 \%$. 


\subsection{Węglan sodu}

5.8. Roztwór węglanu sodu w glicerynie Stosować węglan sodu, roztwór o stężeniu $1 \mathrm{~mol} / \mathrm{l}$ w roztworze gliceryny o ułamku objętościowym $5 \%$, sporządzony przez rozpuszczenie $\mathrm{w}$ kolbie

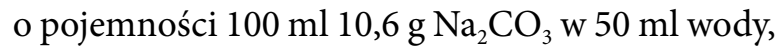
dodanie $5 \mathrm{ml}$ gliceryny oraz uzupełnienie do kreski wodą.

5.9. Roztwór do próby ślepej

Czysty, nieużywany filtr razem $\mathrm{z}$ zaimpregnowaną podkładką celulozową wg punktu 5.18. umieścić w zlewce o pojemności $25 \mathrm{ml}$. Następnie do zlewki dodać porcjami $5 \mathrm{ml}$ kwasu azotowego(V) wg punktu 5.2. i $1 \mathrm{ml}$ kwasu siarkowego(VI) wg punktu 5.4. i ogrzewać ostrożnie na płycie grzejnej w temperaturze około $140{ }^{\circ} \mathrm{C}$ aż do uwolnienia z roztworu tlenków azotu. Po ostudzeniu dodać ostrożnie $2 \mathrm{ml}$ roztworu ditlenku diwodoru wg punktu 5.5. i ogrzewać powoli do uwolnienia tlenu i uzyskania $1 \mathrm{ml}$ roztworu. Zawartość zlewki przenieść ilościowo pięcioma lub sześcioma porcjami roztworu kwasu azotowego(V) wg punktu 5.3. do kolby pomiarowej o pojemności $25 \mathrm{ml}$ i uzupełnić do kreski roztworem kwasu azotowego(V) wg punktu 5.3. - uzyskuje się $\mathrm{w}$ ten sposób nierozcieńczony roztwór do próby ślepej.

Pobrać 2,5 ml przygotowanego nierozcieńczonego roztworu do próby ślepej, przenieść do kolby pomiarowej o pojemności $10 \mathrm{ml}$ i uzupełnić do kreski roztworem kwasu azotowego(V) wg punktu 5.3. - uzyskuje się w ten sposób rozcieńczony roztwór do próby ślepej.

5.10. Roztwór wzorcowy podstawowy arsenu Roztwór wzorcowy arsenu do absorpcji atomowej o stężeniu $1 \mathrm{mg} / \mathrm{ml}$, dostępny w handlu.

5.11. Roztwór wzorcowy pośredni I arsenu Do kolby pomiarowej o pojemności $100 \mathrm{ml}$ odmierzyć $1,00 \mathrm{ml}$ roztworu wzorcowego podstawowego arsenu wg punktu 5.10., uzupełnić do kreski roztworem kwasu azotowego(V) wg punktu 5.3. i dokładnie wymieszać. Stężenie arsenu $\mathrm{w}$ tak przygotowanym roztworze wynosi $10 \mu \mathrm{g} / \mathrm{ml}$. Roztwór przechowywany $\mathrm{w}$ chłodziarce zachowuje trwałość przez dwa tygodnie.

5.12. Roztwór wzorcowy pośredni II arsenu Do kolby pomiarowej o pojemności $10 \mathrm{ml}$ odmierzyć $1,00 \mathrm{ml}$ roztworu wzorcowego pośredniego I wg punktu 5.11. uzupełnić do kreski roztworem kwasu azotowego wg punktu 5.3. i dokładnie wymieszać. Stężenie arsenu $\mathrm{w}$ tak przygotowanym roztworze wynosi $1,00 \mu \mathrm{g} / \mathrm{ml}$. Roztwór należy przygotowywać bezpośrednio przed wykonaniem analizy.

5.13. Roztwór wzorcowy roboczy arsenu Do kolby pomiarowej o pojemności $10 \mathrm{ml}$ odmierzyć $1,00 \mathrm{ml}$ roztworu wzorcowego pośredniego II wg punktu 5.12., dodać $2,5 \mathrm{ml}$ nierozcieńczonego roztworu do próby ślepej wg punktu 5.9., uzupełnić do kreski roztworem kwasu azotowego wg punktu 5.3. i dokładnie wymieszać. Stężenie arsenu w tak przygotowanym roztworze wynosi $100 \mu \mathrm{g} / \mathrm{l}$. Roztwór należy przygotowywać bezpośrednio przed wykonaniem analizy.

5.14. Roztwór arsenu do badania wydajności mineralizacji

Do kolby pomiarowej o pojemności $10 \mathrm{ml}$ odmierzyć $1 \mathrm{ml}$ roztworu wzorcowego podstawowego wg punktu 5.10., uzupełnić do kreski roztworem kwasu azotowego wg punktu 5.3. i dokładnie wymieszać. Stężenie arsenu $\mathrm{w}$ tak przygotowanym roztworze wynosi $100 \mu \mathrm{g} / \mathrm{ml}$.

5.15. Roztwór palladu

Stosować dostępny $\mathrm{w}$ handlu roztwór palladu w postaci azotanu palladu $\left(\mathrm{Pd}\left(\mathrm{NO}_{3}\right)_{2}\right)$ o stężeniu palladu (Pd) $10 \mathrm{~g} / \mathrm{l}$, do absorpcji atomowej.

5.16. Roztwór azotanu(V) magnezu

Stosować dostępny w handlu roztwór azotanu(V) magnezu $\left(\mathrm{Mg}\left(\mathrm{NO}_{3}\right)_{2}\right)$ o stężeniu $10 \mathrm{~g} / \mathrm{l}$, do absorpcji atomowej.

5.17. Roztwór palladu i azotanu magnezu

Przygotować w następujący sposób: pobrać $1 \mathrm{ml}$ roztworu palladu wg punktu 5.15. i $0,1 \mathrm{ml} \mathrm{roz-}$ tworu azotanu(V) magnezu wg punktu 5.16., przenieść do kolby pomiarowej o pojemności $10 \mathrm{ml}$ i uzupełnić do kreski roztworem kwasu azotowego(V) wg punktu 5.3. Roztwór zawiera pallad o stężeniu $1 \mathrm{~g} / \mathrm{l}$ oraz azotan(V) magnezu o stężeniu magnezu $0,6 \mathrm{~g} / \mathrm{l}$.

\subsection{Filtry}

Filtry membranowe $\mathrm{z}$ estrów celulozy o średnicy porów $0,8 \mu \mathrm{m}$ i średnicy odpowiedniej do wybranego próbnika do pobierania frakcji wdychalnej wraz z podkładkami zaimpregnowanymi przez naniesienie odpowiednio do średnicy podkładki 200 lub $400 \mu$ roztworu węglanu sodu $\mathrm{w}$ glicerynie wg punktu 5.8. Podkładki suszyć $\mathrm{w}$ temperaturze pokojowej. Przechowywać w szczelnie zamkniętym pojemniku i zużyć w przeciągu tygodnia od przygotowania. 


\section{Przyrządy pomiarowe i sprzęt pomocniczy}

Stosować typowy sprzęt laboratoryjny oraz następujący:

6.1. Pompa ssąca

Pompa ssąca umożliwiająca pobieranie powietrza ze stałym strumieniem objętości wg Rozdziału 7.

6.2. Próbnik

Próbnik umożliwiający wyodrębnienie $\mathrm{z}$ powietrza frakcji wdychalnej arsenu i jego związków nieorganicznych.

\subsection{Spektrometr}

Spektrometr do absorpcji atomowej z elektrotermiczną atomizacją $\mathrm{w}$ kuwecie grafitowej, z korekcją tła metodą Zeemana, wyposażony w automatyczny podajnik próbek oraz $\mathrm{w}$ lampę $\mathrm{z}$ wyładowaniem bezelektrodowym (EDL) do oznaczania arsenu. Zaleca się stosować kuwety grafitowe z platformą, pokrywane pirolitycznie, do oznaczania pierwiastków lotnych.

\section{Pobieranie próbek powietrza}

Próbki powietrza należy pobierać wg normy PN-Z-04008-07. Przez filtr oraz zaimpregnowaną podkładkę wg punktu 5.18. umieszczone w próbniku wg punktu 6.2. pobrać 480 l powietrza ze strumieniem objętości zalecanym przez producenta próbnika do wyodrębnienia z powietrza frakcji wdychalnej aerozolu (najczęściej 2 1/min).

\section{Warunki pracy spektrometru}

W celu zapewnienia wymaganej czułości i precyzji oznaczania arsenu należy przyjąć następujące warunki pracy spektrometru:

- długość fali - 193,7 nm

- szczelina $-0,7 \mathrm{~nm}$

- całkowita objętość dozowanej próbki - $25 \mu \mathrm{l}$

- objętość dozowanego modyfikatora matrycy $-5 \mu \mathrm{l}$

- temperatura suszenia próbki - $110 \mathrm{i} 130^{\circ} \mathrm{C}$, czas - $75 \mathrm{~s}$

- temperatura spopielania $-700{ }^{\circ} \mathrm{C}$, czas $40 \mathrm{~s}$

- temperatura atomizacji $-2300{ }^{\circ} \mathrm{C}$, czas atomizacji $-5 \mathrm{~s}$

- kuwety grafitowe $\mathrm{z}$ platformą wg punktu 6.3., pokrywane pirolitycznie, ogrzewane poprzecznie, do oznaczania pierwiastków lotnych.
Szczegółowy program temperaturowy pracy pieca i pozostałe parametry pracy należy dobrać w zależności od indywidualnych możliwości aparatu i zaleceń producenta.

\section{Sporządzanie krzywej wzorcowej}

Wykonać dwukrotny pomiar absorbancji integralnej roztworów arsenu o stężeniach: 0,$00 ; 5,00$; 25,$00 ; 50,00 ; 75,00$ i $100,00 \mu \mathrm{g} / \mathrm{l}$, sporządzanych przez automatyczny podajnik próbek z roztworu wzorcowego roboczego o stężeniu 100,00 $\mu \mathrm{g} / \mathrm{l} \mathrm{wg}$ punktu 5.13. Jednocześnie $\mathrm{z}$ roztworem wzorca dozować modyfikator matrycy: $5 \mu$ l roztworu palladu i azotanu magnezu wg punktu 5.17. Roztwór stosowany do rozcieńczania wzorca stanowi rozcieńczony roztwór próbki zerowej po mineralizacji wg punktu 5.9. Całkowita objętość dozowanego do kuwety roztworu wynosi $25 \mu \mathrm{l}$. Po przyjęciu ustalonych wg Rozdziału 8 warunków pracy spektrometru wykonać dwukrotnie pomiar absorbancji integralnej każdego z wzorców arsenu.

Krzywą wzorcową sporządzić, korzystając z funkcji wzorcowania spektrometru i komputerowego zbierania danych analitycznych zgodnie $\mathrm{z}$ instrukcją użytkowania.

Krzywą wzorcową należy sporządzać bezpośrednio przed wykonaniem oznaczania.

\section{Wykonanie oznaczania}

Filtr $\mathrm{z}$ zaimpregnowaną podkładką wg punktu 5.18., na który pobrano próbkę powietrza, umieścić w zlewce o pojemności $25 \mathrm{ml}$. Następnie do zlewki dodać porcjami $5 \mathrm{ml}$ kwasu azotowego(V) wg punktu 5.2. i $1 \mathrm{ml}$ kwasu siarkowego(VI) wg punktu 5.4. i ogrzewać ostrożnie na płycie grzejnej w temperaturze około $140^{\circ} \mathrm{C}$ aż do uwolnienia $\mathrm{z}$ roztworu tlenków azotu. Po ostudzeniu zlewek dodać do nich ostrożnie $2 \mathrm{ml}$ ditlenku diwodoru wg punktu 5.5. i ogrzewać do uwolnienia tlenu i uzyskania $1 \mathrm{ml}$ roztworu. Zawartość zlewki przenieść ilościowo pięcioma lub sześcioma porcjami roztworu kwasu azotowego(V) wg punktu 5.3. do kolby pomiarowej o pojemności $25 \mathrm{ml}$ i uzupełnić do kreski roztworem kwasu azotowego(V) wg punktu 5.3. Pobrać $2,5 \mathrm{ml}$ roztworu próbki, przenieść do kolby pomiarowej o pojemności $10 \mathrm{ml}$ i uzupełnić do kreski roztworem kwasu azotowego(V) wg punktu 5.3. - uzyskuje się w ten sposób roztwór do badania. 
Wykonać dwukrotny pomiar absorbancji roztworu do badania i rozcieńczonego roztworu do próby ślepej wg punktu 5.9., zachowując takie same warunki pomiarowe jak przy sporządzaniu krzywej wzorcowej wg Rozdziału 9. Stężenie arsenu $\mathrm{w}$ roztworze do badania i roztworze do próby ślepej podawane jest automatycznie.

Jeżeli oznaczone stężenie arsenu w roztworze do badania przekroczy zakres krzywej wzorcowej, roztwór należy rozcieńczyć rozcieńczonym roztworem do próby ślepej wg punktu 5.9. lub skorzystać $\mathrm{z}$ automatycznego rozcieńczania próbki przez podajnik próbek. Wykonać pomiar absorbancji badanego roztworu po rozcieńczeniu, a krotność rozcieńczenia próbki $(k)$ uwzględnić przy obliczaniu wyniku oznaczania wg Rozdziału 12.

\section{Sprawdzanie wydajności mineralizacji}

Na sześć filtrów membranowych wraz z impregnowanymi podkładkami wg punktu 5.18., umieszczonymi w zlewkach o pojemności $25 \mathrm{ml}$, nanieść po $80 \mu \mathrm{l}$ roztworu do badania wydajności mineralizacji arsenu o stężeniu $100 \mu \mathrm{g} / \mathrm{ml}$ wg punktu 5.14. i pozostawić do wyschnięcia do następnego dnia. Następnie do zlewki dodać porcjami $5 \mathrm{ml}$ kwasu azotowego wg punktu 5.2. i $1 \mathrm{ml}$ kwasu siarkowego wg punktu 5.4. i ogrzewać ostrożnie na płycie grzejnej w temperaturze około $140{ }^{\circ} \mathrm{C}$ aż do uwolnienia $\mathrm{z}$ roztworu tlenków azotu. Po ostudzeniu zlewek dodać do nich ostrożnie $2 \mathrm{ml}$ ditlenku diwodoru wg punktu 5.5. i ogrzewać powoli do uwolnienia tlenu i uzyskania $1 \mathrm{ml}$ roztworu. Zawartość zlewki przenieść ilościowo pięcioma lub sześcioma porcjami roztworu kwasu azotowego(V) wg punktu 5.3. do kolby pomiarowej o pojemności $25 \mathrm{ml}$ i uzupełnić do kreski roztworem kwasu azotowego(V) wg punktu 5.3. Z kolby pomiarowej pobrać $2,5 \mathrm{ml}$ roztworu próbki, przenieść do kolby pomiarowej o pojemności $10 \mathrm{ml}$ i uzupełnić do kreski roztworem kwasu azotowego(V) wg punktu 5.3. - uzyskuje się w ten sposób roztwór do badania. Jednocześnie przygotować w identyczny sposób z czystego filtra roztwór kontrolny.

Przygotować także trzy roztwory porównawcze przez odmierzenie bezpośrednio do kolb pomiarowych o pojemności $25 \mathrm{ml}$ po $80 \mu$ roztworu arsenu do badania wydajności mineralizacji arsenu o stężeniu $100 \mu \mathrm{l} / \mathrm{ml}$ wg punktu 5.14. Rozcieńczyć próbki przez pobranie $2,5 \mathrm{ml}$ przygotowanego roztworu do kolby o pojemności $10 \mathrm{ml}$, dodanie 2,5 $\mathrm{ml}$ roztworu nierozcieńczonej próbki ślepej wg punktu 5.9. i uzupełnienie do kreski roztworem kwasu azotowego(V) wg punktu 5.3.

Wykonać dwukrotny pomiar absorbancji integralnej roztworów do badania wydajności mineralizacji i rozcieńczonego roztworu do próby ślepej oraz roztworów porównawczych po przyjęciu ustalonych wg Rozdziału 8 warunków pracy spektrometru.

Współczynnik wydajności mineralizacji arse$\mathrm{nu}\left(w_{m}\right)$ obliczyć wg wzoru:

$$
w_{m}=\frac{C_{d}-C_{o}}{\bar{C}_{p}},
$$

w którym:

$C_{d}-$ stężenie arsenu w roztworze do badania wydajności mineralizacji, w mikrogramach na litr;

$C_{o}-$ stężenie arsenu w rozcieńczonym roztworze do próby ślepej, w mikrogramach na litr;

$\bar{C}_{p}-\quad$ średnie stężenie arsenu $\mathrm{w}$ roztworach porównawczych, w mikrogramach na litr.

Następnie obliczyć średnią wartość współczynnika wydajności mineralizacji arsenu $\left(\bar{w}_{m}\right)$ jako średnią arytmetyczną otrzymanych wartości $w_{m}$. Dla opisanego powyżej sposobu mineralizacji

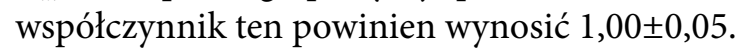

\section{Obliczanie wyniku oznaczania}

Stężenie arsenu i jego związków nieorganicznych $(X)$ oznaczonych jako arsen, w badanym powietrzu, obliczyć w miligramach na metr sześcienny wg wzoru:

$$
X=\frac{\left(C-C_{0}\right) \cdot V_{1}}{V \cdot \bar{w}_{m} \cdot 1000} \cdot k,
$$

w którym:

C - stężenie arsenu w roztworze do badania, w mikrogramach na litr;

$C_{0}$ - stężenie arsenu w rozcieńczonym roztworze do próby ślepej, w mikrogramach na litr;

$V_{1}$ - objętość roztworu do badania, w mililitrach $\left(V_{1}=10 \mathrm{ml}\right)$; 
$V$ - objętość powietrza przepuszczonego przez filtr, w litrach;

$\bar{w}_{m}-$ średnia wartość współczynnika wydajności mineralizacji;

$k$ - krotność rozcieńczenia $(k=10)$.

Adres do korespondencji/Contact details: dr MAtGORZATA POŚNIAK

e-mail:mapos@ciop.pl

Centralny Instytut Ochrony Pracy -

Państwowy Instytut Badawczy

00-701 Warszawa, ul. Czerniakowska 16

POLAND 
